\title{
Female wages in the Egyptian textiles and clothing industry: Low pay or discrimination?
}

Amirah El-Haddad

Follow this and additional works at: https://knowledgecommons.popcouncil.org/departments_sbsr-pgy

Part of the Demography, Population, and Ecology Commons, Family, Life Course, and Society Commons, Gender and Sexuality Commons, International Public Health Commons, Labor Economics Commons, and the Work, Economy and Organizations Commons How does access to this work benefit you? Let us know!

\section{Recommended Citation}

El-Haddad, Amirah. 2011. "Female wages in the Egyptian textiles and clothing industry: Low pay or discrimination?" Gender and Work in the MENA Region Working Paper no. 13. Cairo: Population Council. 


\section{NUMBER 13}

JUNE 2011

GENDER AND WORK IN THE MENA REGION

WORKING PAPER SERIES

Poverty, Job Quality and Labor Market Dynamics

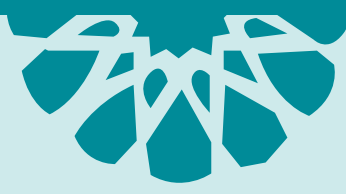

Female Wages in the Egyptian

Textiles and Clothing Industry:

Low Pay or Discrimination?

Amirah El-Haddad

12 Population Council 
Amirah El-Haddad is an Associate Professor at the Faculty of Economics and Political Science, Cairo University, and a Research Associate of the Economic Research Forum, Cairo, Egypt.

Email: Amirah.elhaddad@gmail.com

The research presented in this publication is the result of a project funded by Canada's International Development Research Centre (www.idrc.ca).

\title{
IDRC * CRDI
}

Canadà

\section{(f) Population Counal \\ Research that makes a difference}

The Population Council confronts critical health and development issues-from stopping the spread of HIV to improving reproductive health and ensuring that young people lead full and productive lives. Through biomedical, social science and public health research in 50 countries, the Council works with our partners to deliver solutions that lead to more effective policies, programs, and technologies to improve lives worldwide. Established in 1952 and headquartered in New York, the Council is a nongovernmental, nonprofit organization with an international board of trustees.

\author{
Population Council \\ Egypt Office \\ 59 Misr Helwan Agricultural Road, Maadi, Cairo, Egypt \\ Tel.: (+202) 2525-5965, (+202) 2525-5967, (+202) 2525-5968 \\ Facsimile: (+202) 2525-5962 \\ Website: http://www.popcouncil.org \\ Email: pcouncil@popcouncil.org \\ (C) 2011 The Population Council, Inc. \\ Any part of this publication may be reproduced without permission for limited distribution, provided \\ it is distributed without charge and the Population Council is acknowledged as its source. The \\ Population Council would appreciate receiving a copy of any materials in which the text is used.
}

ISSN: 11881/2011 
NUMBER 13

JUNE 2011

GENDER AND WORK IN THE MENA REGION WORKING PAPER SERIES

Poverty, Job Quality and Labor Market Dynamics

Female Wages in the Egyptian

Textiles and Clothing Industry:

Low Pay or Discrimination?

Amirah El-Haddad

(2) Population Council 



\section{Table of contents}

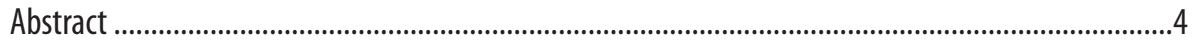

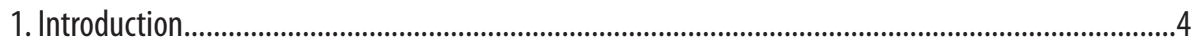

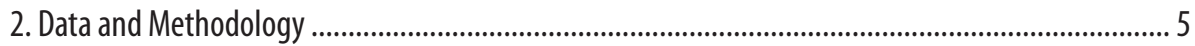

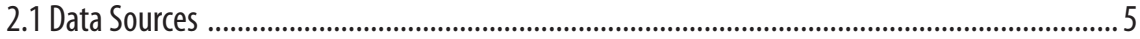

2.1.1 Firm Level Survey …………………………………………………………… 6

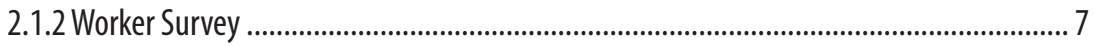

2.2 Sample Descriptives ........................................................................................................

2.2.1 Sector Employment by Gender ............................................................................... 7

2.2.2 Sample Gender and Wage Distribution by Occupation ..................................................9

2.2.3 Sample Gender and Wage Distribution by Firm Characteristics ...................................16

2.2.4 Employer's Gender Preference ..................................................................................

2.3 Background .....................................................................................................................

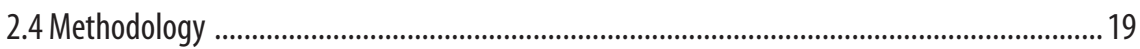

2.4.1 Mathematical Representation ................................................................................ 19

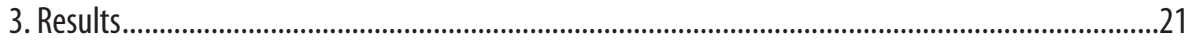

3.1 Wage Equation Regression Results ..................................................................................2

3.1.1 Occupational Characteristics .................................................................................. 21

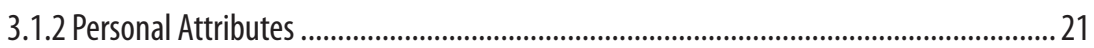

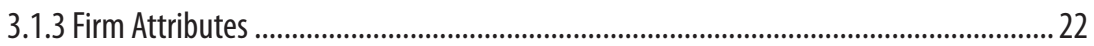

3.2 Decomposition Results .....................................................................................................

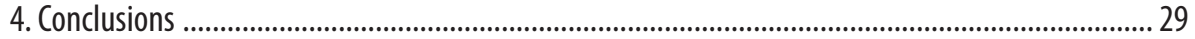

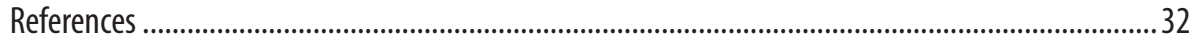

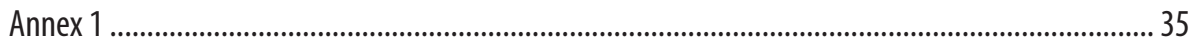

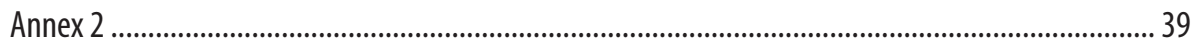




\section{Abstract}

Analysis of the wage gap has most usually been carried out across the formal sector as a whole, missing nuances of differences in pay in specific occupations. This paper analyzes data from a new survey of firms and workers in the textiles and clothing sector collected in 2009. These data allow for the explanation of the sector's gender wage gap by poorer endowments, relegation of women to low-paying firms and occupations, and by within-firm and within-occupation differential in returns. There is a pay gap in this sector, with men receiving an hourly wage 29 percent higher than that of women. This gap arises partly as women are concentrated in the lower paid occupations and the lower-paying firms. There is clear glass ceiling in effect with women least represented in the highest paying management positions. Somewhat surprisingly, differences in returns favor women, and the intra-occupational pay gap is reversed once characteristics, including firm characteristics, are controlled for. Failure to control for firm characteristics (as in most studies) will over-estimate the gap. Outright discrimination is the sole reason for discrimination within the sector and could be partially explained by the difference between the role society expects of men and that it expects of women, the for mer being the main bread earner. The largest of the pay gap (more than 70 percent)is attributable to differences in endowments, such as worker education and experience. Thus, closing the pay gap is not just a matter of equal pay for equal work, as is now being discussed in Egypt, but of enhancing women's capabilities to ensure equality of opportunity upon entering the labor force.

\section{Introduction}

Textiles and clothing play an important role in Egypt's economy, notably their contribution to employment, value added, and foreign exchange earnings. Textile and clothing enterprises account for one-fifth of all industrial sector firms, being the largest single employer with over 400,000 workers, that is almost a quarter of the industrial labor force (Industrial Development Authority 2009). In 2008 the industry accounted for 26.4 percent of industrial production with a total value added of LE 33.5 billion (Ministry of State for Economic Development (MOED) 2008), and close to Io percent of the country's exports (International Trade Centre 2008). The government has long utilized this sector to absorb 
Egypt's growing labor force and help tackle unemployment problems and generate incomes for about half a million Egyptian families. The growth of the sector was hoped to move workers from the informal sector with worse, less secure, working conditions and low returns.

As of the late I990s, the TC sector has increasingly attracted female workers. Increasing employment was a consequence of the growing private sector, both as public firms were privatized or more specifically neglected (El-Haddad 20IO), but more particularly from the entry of new private firms in the newly liberalized economic environment following the adoption of the Economic Reform and Structural Adjustment Program (ERSAP) in I99I. In fact the entire increase in private sector employment between 1998 and 2006 was on account of the feminization of these two sectors (Assaad and El-Hamidi 2009). Many more women are employed in TC compared to the average national level: at the national level in 2007 just under $20 \%$ (just over $20 \%$ ) of the private sector (overall) labor force were women whereas in textiles and clothing (TC) this share doubles to about $40 \%$.

However, labor intensive industries, especially those producing for the export market, have often been criticized for providing only low wage employment, especially for women. So can the TC sector in Egypt be expected to yield a living wage, especially for women who are either in lower paid occupations or suffer from wage discrimination? To answer this question, this paper examines the gender wage gap in Egypt's TC sector. Specifically, the paper analyzes data from a new survey of firms and workers in the TC sector collected in 2009 . These data allow for the explanation of the sector's gender wage gap by poorer endowments, relegation of women to low-paying firms and occupations and by withinfirm and within-occupation differential in returns. These results are presented as a Oaxaca decomposition controlling for both worker and firm characteristics.

The paper is divided into four sections. The second presents data and methodology employed in this paper. Results are discussed in the third section of the paper. The fourth section concludes.

\section{Data and Methodology}

\subsection{Data Sources}

Two new data sets-a firm questionnaire covering 275 TC firms and a worker questionnaire covering 5,383 TC workers-were collected in September, 2009. ${ }^{1}$ This paper uses the latter. The following two sections briefly describe the questionnaire and sampling design.

1 The survey was conducted by the Cabinet's Information and Decision Support Center (IDSC). 


\subsubsection{Firm Level Survey}

The firm survey comprised six modules: basic firm data, firm activity, production, sales, exports and employment, trends after the financial crisis, job opportunities, and future plans. Table I gives a breakdown of sampled firms.

Firms were sampled based on a combination of two sample frames provided by the Egyptian Federation of Industries. ${ }^{2}$ Unfortunately, the final frame does not reflect the true number of firms in the TC industry in Egypt. There simply is not any comprehensive, accurate and detailed frame that includes basic firm level data to ensure a representative sample. The 275 firms covered the governorates of Greater Cairo, Alexandria and El-Sharkyia; these three include more than 90 percent of Egypt's TC firms. Greater Cairo comprises the governorates of Cairo, Giza, 6th of October, Helwan and El-Qalyubia.

Stratified sampling was used to ensure sufficient representation of large sized and exporting firms. The resulting geographical distribution of sampled firms was very similar to that in the sample frame (Table I). Tables 2 and 3 give a breakdown of sampled firms by activity, market orientation, ownership and firm size.

Table 1: Sample Firm Distribution by Location

\begin{tabular}{|l|c|c|c|c|}
\hline & \multicolumn{2}{|c|}{ No. \& \% of firms in the sample } & \multicolumn{2}{c|}{ No. \& \% of firms in sample frame } \\
\hline Greater Cairo & 181 & $66 \%$ & 820 & $70 \%$ \\
\hline Alexandria & 60 & $22 \%$ & 253 & $22 \%$ \\
\hline El-Sharkyia & 34 & $12 \%$ & 99 & $8 \%$ \\
\hline & 275 & $100 \%$ & 1172 & $100 \%$ \\
\hline
\end{tabular}

Source: Author's calculation based on Egyptian Federation of Industries Sample Frame and IDSC Sampling Design.

Table 2: Sample Firm Distribution by Activity, Market Orientation and Ownership

\begin{tabular}{|l|c|c|c|c|c|c|c|c|}
\hline \multicolumn{3}{|c|}{ Activity } & \multicolumn{3}{c|}{ Market Orientation } & \multicolumn{3}{c|}{ Ownership } \\
\hline & Textiles & Clothing & \multicolumn{2}{|c|}{ Exporting } & $\begin{array}{c}\text { Non- } \\
\text { exporting }\end{array}$ & $\begin{array}{c}\text { Public } \\
\text { sector }\end{array}$ & $\begin{array}{c}\text { Private } \\
\text { sector }\end{array}$ & Total \\
\hline \multicolumn{8}{|c|}{ QIZ } & Non-QIZ \\
\hline $\begin{array}{l}\text { No. of } \\
\text { firms }\end{array}$ & 97 & 178 & 53 & 40 & 182 & 6 & 169 & 275 \\
\hline$\%$ & $35 \%$ & $65 \%$ & $19 \%$ & $15 \%$ & $66 \%$ & $2 \%$ & $98 \%$ & $100 \%$ \\
\hline
\end{tabular}

Source: IDSC TC Firm Questionnaire (2009).

2 This means that firms in the informal sector are excluded. 
Table 3: Sample Firm Distribution by Firm Size*

\begin{tabular}{|l|c|c|c|c|}
\hline & Small & Medium & Large & Total \\
\hline $\begin{array}{l}\text { No. of firms in the } \\
\text { sample }\end{array}$ & 125 & 115 & 35 & 275 \\
\hline$\%$ & $45 \%$ & $42 \%$ & $13 \%$ & $100 \%$ \\
\hline $\begin{array}{l}\text { Share in real } \\
\text { weighted } \\
\text { production }\end{array}$ & $5 \%$ & $10 \%$ & $85 \%$ & $100 \%$ \\
\hline
\end{tabular}

Source: IDSC TC Firm Questionnaire 2009. *Small firms: up to 50 workers, medium: greater than 50 and up to 500 workers, and large: over 500 workers.

\subsubsection{Worker Survey}

The worker questionnaire was divided into five modules: basic characteristics, work conditions, skills and training, job satisfaction, and crisis effects. The sample was stratified by four size categories: less than Io workers, from Io to IOO, from IO० to I,O००, and larger than I,O०० workers (Table 4); 5,590 workers were to be surveyed however, due to practical problems in the field, only 5,383 questionnaires were completed.

Table 4: Sample Worker Distribution

\begin{tabular}{|l|c|c|c|}
\hline $\begin{array}{c}\text { Firm category } \\
\text { (no. of workers) }\end{array}$ & $\begin{array}{c}\text { No. of sampled } \\
\text { firms (1) }\end{array}$ & $\begin{array}{c}\text { No. of workers } \\
\text { sampled from each } \\
\text { firm in category (2) }\end{array}$ & $\begin{array}{c}\text { No. of sampled } \\
\text { workers in category } \\
(3)=(1) *(2)\end{array}$ \\
\hline Less than 10 & 100 & 5 & 500 \\
\hline $10-100$ & 101 & 20 & 2,020 \\
\hline $\begin{array}{l}\text { Greater than100- } \\
1,000\end{array}$ & 63 & 40 & 2,520 \\
\hline More than 1,000 & 11 & 50 & 550 \\
\hline Total & 275 & & 5,590 \\
\hline
\end{tabular}

Source: IDSC Worker Survey Sampling Note (2009).

\subsection{Sample Descriptives}

\subsubsection{Sector Employment by Gender}

This analysis covers only permanent public and private sector workers, which are non- seasonal and non- part-time workers, reducing the sample to 5,200 workers. Women are known to be heavily concentrated in the TC sector. Indeed, many more women are employed in TC compared to the average national level. At the national level just under $20 \%$ (just over 
$20 \%)$ of the private sector (overall) labor force are females whereas in textiles and clothing (TC) this share doubles to about $40 \%$ (Table 5). As of the late I990s, two sectors increasingly attracted female workers, namely food processing and textiles and clothing. In fact, the entire increase in private sector employment between 1998 and 2006 was on account of the feminization of these two sectors (Assaad and El-Hamidi 2009).

Table 5: National and Sample TC Employment by Gender $(2007,2009)$

\begin{tabular}{|l|c|c|c|}
\hline \multirow{2}{*}{} & Employment in TC & \multicolumn{2}{|c|}{ National Employment } \\
\hline \multirow{2}{*}{ Sample IDSC 2009 } & \multicolumn{2}{|c|}{ CAPMAS 2007 (in millions) } \\
\cline { 3 - 4 } & & Public + Private & Private Sector \\
\hline & 3,243 & 17.1 & 12.6 \\
\hline Female & $62 \%$ & $78 \%$ & $81 \%$ \\
\hline & 1,957 & 4,7 & 2.9 \\
\hline \multirow{2}{*}{ Total } & $38 \%$ & $22 \%$ & $19 \%$ \\
\hline & 5,200 & 21.8 & 15.5 \\
\cline { 2 - 4 } & $100 \%$ & $100 \%$ & $100 \%$ \\
\hline
\end{tabular}

Source: Central Agency for Public Mobilization and Statistics (CAPMAS), Annual Statistical Book, Various issues. IDSC TC Worker Questionnaire 2009.

Compared to the sector data, at the national level the distribution of men and women in the sample is closer to that of the private sector, so whilst women represent $38 \%$ of all TC workers in the sample they represent just a quarter $(26 \%)$ in overall sector employment at the national level (Table 6). But the share is close to that of the private sector (34\%). This is hardly surprising since most public sector firms are textiles firms rather than clothing firms. Clothing firms are more likely to hire larger numbers of women than men, especially for their relatively substantial sewing activity.

Table 6: TC National and Sample Employment by Gender $(2007,2009)$

\begin{tabular}{|l|c|c|c|}
\hline & Sample IDSC 2009 & \multicolumn{2}{|c|}{ CAPMAS 2006 } \\
\hline & & Public + Private & Private Sector \\
\hline Male & 3,243 & 206,421 & 115,315 \\
\hline & $62 \%$ & $74 \%$ & $66 \%$ \\
\hline Female & 1,957 & 71,846 & 58,446 \\
\hline & $38 \%$ & $26 \%$ & $34 \%$ \\
\hline Total & 5,200 & 278,267 & 173,761 \\
\hline & $100 \%$ & $100 \%$ & $100 \%$ \\
\hline
\end{tabular}

Source: Central Agency for Public Mobilization and Statistics (CAPMAS), Annual Statistical Book, Various issues. IDSC TC Worker Questionnaire 2009. 
According to the sample, most women working in the sector are relatively young (average age of 28 compared to 36 for men) and unmarried $(62 \%)$ (Table 7$)$. Men have attained relatively higher educational levels compared to women (Table 8 ); $15 \%$ of all sampled men have a university or post-university degree compared to only $9 \%$ of all women. These differences in education reflect the disproportionate hiring of men at more senior levels, as discussed below.

Table 7: Marital Status by Gender

\begin{tabular}{|l|c|c|c|}
\hline \multirow{2}{*}{ Unmarried } & Men & Women & Total \\
\hline \multirow{2}{*}{ Married } & 845 & 1,220 & 2,065 \\
\hline \multirow{2}{*}{ Total } & $26 \%$ & $62 \%$ & \\
\cline { 2 - 4 } & 2,398 & 737 & 3,135 \\
\cline { 2 - 4 } & $74 \%$ & $38 \%$ & \\
\cline { 2 - 4 } & 3,243 & 1,957 & 5,200 \\
\hline
\end{tabular}

Source: Author's calculations based on IDSC TC Worker Questionnaire 2009.

Table 8: Educational Attainment by Gender

\begin{tabular}{|l|l|c|c|c|}
\hline \multicolumn{2}{|c|}{} & Men & Women & Total \\
\hline \multirow{2}{*}{ Illiterate } & Frequency & 314 & 208 & 522 \\
\cline { 2 - 5 } & Share of all men (women) & $9 \%$ & $10 \%$ & $10 \%$ \\
\hline \multirow{2}{*}{ Read \& Write } & Frequency & 1,136 & 752 & 1,888 \\
\cline { 2 - 5 } & Share of all men (women) & $34 \%$ & $37 \%$ & $35 \%$ \\
\hline \multirow{2}{*}{$\begin{array}{l}\text { Secondary \& } \\
\text { Postsecondary }\end{array}$} & Frequency & 1,391 & 881 & 2,272 \\
\cline { 2 - 5 } $\begin{array}{l}\text { University \& } \\
\text { Post University }\end{array}$ & Share of all men (women) & $41 \%$ & $44 \%$ & $42 \%$ \\
\cline { 2 - 5 } & Srequency & 517 & 184 & 701 \\
\hline \multirow{2}{*}{ Total } & Frequency of all men (women) & $15 \%$ & $9 \%$ & $13 \%$ \\
\cline { 2 - 5 } & Share of all men (women) & 3,358 & 2,025 & 5,383 \\
\hline
\end{tabular}

Source: Author's calculations based on IDSC TC Worker Questionnaire 2009.

\subsubsection{Sample Gender and Wage Distribution by Occupation}

The distribution of men and women into the various occupations along the TC occupational structure shows a degree of occupational segregation. Men are disproportionately represented in the upper, more powerful professions, such as supervisors, managers, executives, and production operators (Table 7 ). On the other hand, women tend to be over-represented in the lowest-ranking, lowest-paid occupations in the workforce, such 
as secretaries, sewing machine operators, and sales associates. That is, occupations are "sex typed" as either being specifically male or female jobs. Unsurprisingly, the largest single occupation, accounting for $56 \%$ of all workers, is factory workers. Nearly half of all men (47\%) occupy this category whilst for women the figure is $7 \mathrm{r} \%$.

Table 7: Sample 0ccupation Breakdown by Gender and Gender Breakdown by 0ccupation

\begin{tabular}{|c|c|c|c|}
\hline & Men & Women & Total \\
\hline \multicolumn{4}{|c|}{ Managerial Positions (e.g. executives, supervisors, production operators) (1) } \\
\hline Frequency & 183 & 52 & 235 \\
\hline Gender share in occupation (\%) & 78 & 22 & 100 \\
\hline Share of all men (women) (\%) & 5.6 & 2.7 & 4.5 \\
\hline \multicolumn{4}{|c|}{ Specialists ("those holding scientific positions", e.g. engineers) (2) } \\
\hline Frequency & 239 & 60 & 299 \\
\hline Gender share in occupation (\%) & 80 & 20 & 100 \\
\hline Share of all men (women) (\%) & 7.4 & 3.1 & 5.8 \\
\hline \multicolumn{4}{|c|}{ Specialists) helpers and technicians (3) } \\
\hline Frequency & 444 & 50 & 494 \\
\hline Gender share in occupation (\%) & 90 & 10 & 100 \\
\hline Share of all men (women) (\%) & 13.7 & 2.6 & 9.5 \\
\hline \multicolumn{4}{|c|}{ Office administrative positions (4) } \\
\hline Frequency & 154 & 79 & 233 \\
\hline Gender share in occupation (\%) & 66 & 34 & 100 \\
\hline Share of all men (women) (\%) & 4.8 & 4.0 & 4.5 \\
\hline \multicolumn{4}{|c|}{ Workers in services, in shops and markets(e.g. sellers of clothing) (5) } \\
\hline Frequency & 29 & 6 & 35 \\
\hline Gender share in occupation (\%) & 83 & 17 & 100 \\
\hline Share of all men (women) (\%) & 0.9 & 0.3 & 0.7 \\
\hline \multicolumn{4}{|l|}{ Handicraftsmen (7) } \\
\hline Frequency & 386 & 252 & 638 \\
\hline Gender share in occupation (\%) & 61 & 40 & 100 \\
\hline Share of all men (women) (\%) & 12 & 13 & 12 \\
\hline \multicolumn{4}{|c|}{ Factory workers, machinery workers and assembly workers (8) } \\
\hline Frequency & 1,519 & 1,383 & 2,902 \\
\hline Gender share in occupation (\%) & 52 & 48 & 100 \\
\hline Share of all men (women) (\%) & 47 & 71 & 56 \\
\hline
\end{tabular}




\begin{tabular}{|l|c|c|c|}
\hline \multicolumn{4}{|l|}{ Ordinary workers (e.g. maids, cleaners, office boys...etc.) (9) } \\
\hline Frequency & 289 & 75 & 364 \\
\hline Gender share in occupation (\%) & 79 & 21 & 100 \\
\hline Share of all men (women) (\%) & 9 & 4 & 7 \\
\hline \multirow{2}{*}{ Total } & 3,243 & 1,957 & 5,200 \\
\cline { 2 - 4 } & $62 \%$ & $38 \%$ & 100 \\
\hline
\end{tabular}

Source: IDSC Worker Questionnaire, 2009. Occupation codes in brackets. Codes utilized here follow the Standard Occupational Classification Manual (2005) (IDSC, Ministry for Labor Force and Immigration, Social Fund for Development, CAPMAS, National Committee for data Review and Auditing, 2005).

Table 8 gives the average hourly wage for each occupation in the sample. The higher the occupational code, the lower the occupational status and the lower the wage rate. So whilst the average hourly wage reaches about six (LE5.6I) Egyptian pounds for management positions, it drops by $60 \%$ to just above two pounds (LE2.24) for office boys and cleaners.

Table 8: Log Hourly and Hourly Wage by Occupation (in LE)

\begin{tabular}{|l|c|c|}
\hline & Log Hourly Wage & Hourly Wage \\
\hline $\begin{array}{l}\text { Managerial Positions (e.g. executives, supervisors, } \\
\text { production operators) (1) }\end{array}$ & 1.62 & 5.61 \\
\hline $\begin{array}{l}\text { Specialists ("those holding scientific positions", e.g. } \\
\text { engineers) (2) }\end{array}$ & 1.31 & 4.33 \\
\hline Specialists) helpers and technicians (3) & 1.14 & 3.48 \\
\hline Office administrative positions (4) & 1.04 & 3.10 \\
\hline $\begin{array}{l}\text { Workers in services, in shops and markets(e.g. sellers } \\
\text { of clothing) (5) }\end{array}$ & 1.05 & 3.16 \\
\hline Handicraftsmen (7) & 1.02 & 3.14 \\
\hline $\begin{array}{l}\text { Factory workers, machinery workers and assembly } \\
\text { workers (8) }\end{array}$ & 0.85 & 2.55 \\
\hline Ordinary workers (e.g. maids, cleaners, office boys...etc.) (9) & 0.73 & 2.24 \\
\hline Total & 0.96 & 2.96 \\
\hline
\end{tabular}

Source: IDSC Worker Questionnaire, 2009. Note on occupational codes as in Table 7 above.

Figure I shows an increasing trend for females' share into lower paying occupations, whereas the opposite is the case for men (of course, as it is the opposite side of the same coin). Accordingly, the distribution of men and women along the TC occupational structure - before controlling for characteristics - supports the glass ceiling hypothesis. This hypothesis argues that women are stopped at a lower level within the hierarchy of 
an organization due to discrimination. The ceiling or barrier preventing women from advancing is believed to be not immediately apparent and is usually an unwritten and unofficial or informal policy hence, the term glass (i.e. transparent and so can't be seen, that is, it is not written down anywhere).

The first three occupations (I, 2 and 3 ) represent the stereotypically "male jobs", in which $80 \%-90 \%$ of the workers are men (Table 7 above, FigureI). Average wages in these three occupations are higher than those in occupations 7 and 8 , in which $40 \%$ and $48 \%$ of the jobholders are women (compared to $38 \%$ of all occupations). This segregation of women into less-prestigious and lower-paid jobs decreases a woman's opportunity for promotion, as well as her chance of having any type of substantial management function over other employees.

Figure 1: Share in 0ccupational Categories by Gender

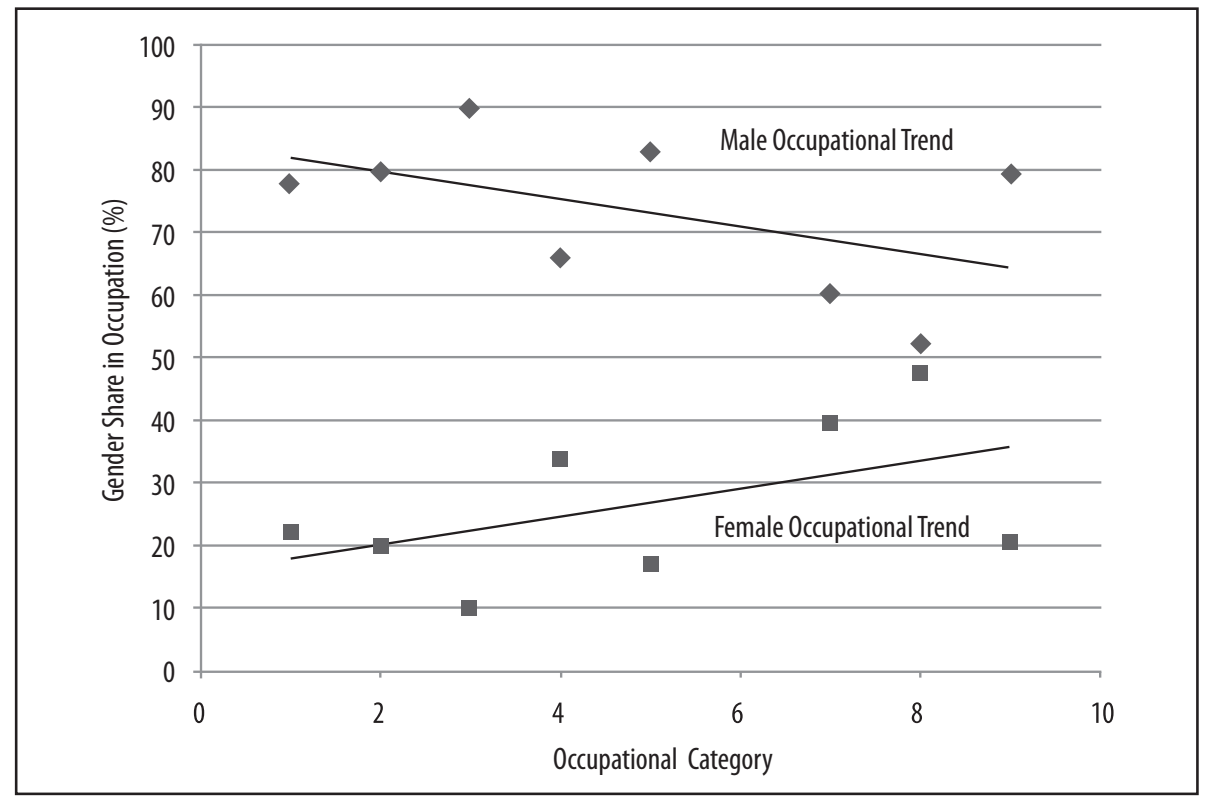

Source: IDSC Worker Questionnaire, 2009. Note on occupational codes as in Table 7 above.

Figure 2 also shows that occupation(s) with the most women has (have) nearly the lowest hourly average wage and that occupation(s) with the highest average wage have a small share of women. 
Figure 2: Female Share in 0ccupational Category against Hourly Wage

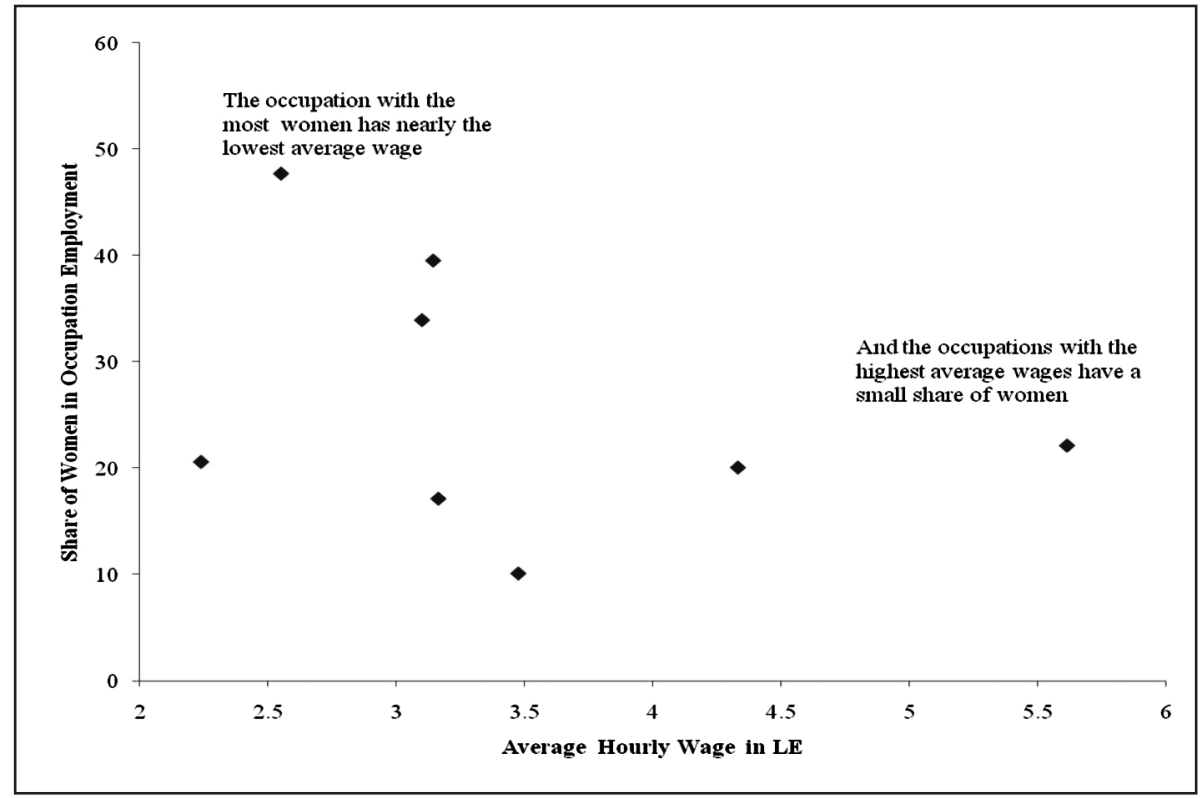

Source: Author's calculations based on IDSC Worker Questionnaire, 2009. Note on occupational codes as in Table 7 above.

But are women discriminated against in pay within each occupational category? Figure 3 depicts the distribution of hourly wages across occupations by gender. The figure shows that women earn systematically lower hourly wages than men in every single occupational category. Figure 4 shows that women are least concentrated in occupations with nearly identical hourly wage (e.g. occupation 3). The largest difference in pay is in the professionals and specialists' category (occupation 2) where women's share represents only $20 \%$. Table 9 gives the same information. 
Figure 3: Hourly Wage Distribution by Gender and Occupation (in LE)

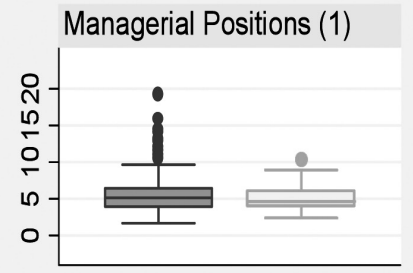

Specialists and Engineers (2) Specialists' Helpers (3)
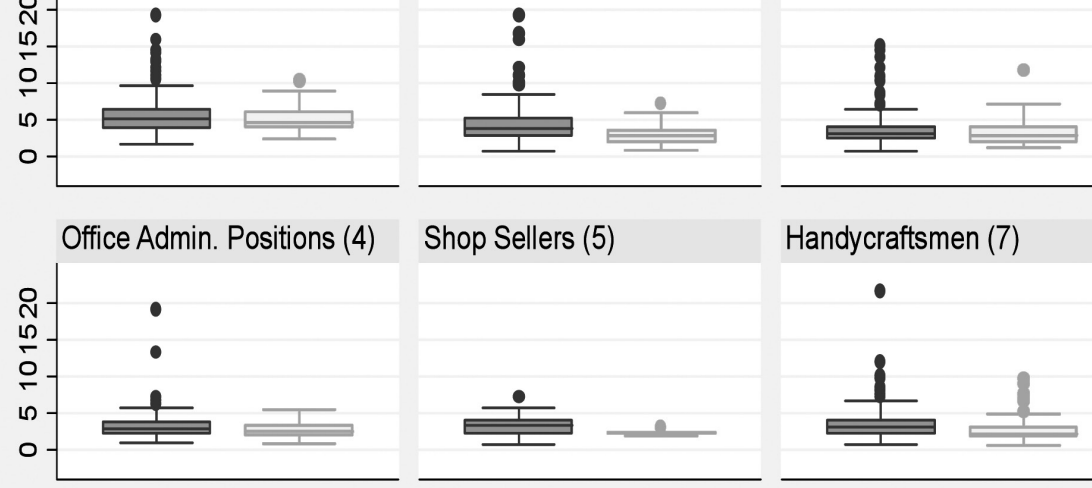

Shop Sellers (5)

Handycraftsmen (7)

Machin. \& Assembly Work.(8) Ordinary Occupations (9)
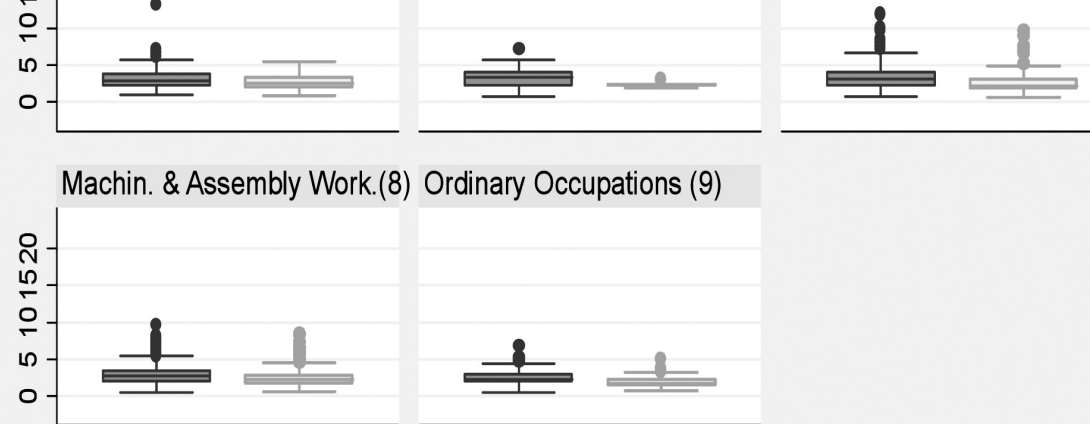

Male Hourly Wage

Female Hourly Wage

Source: Author's calculations based on IDSC Worker Questionnaire, 2009.

Figure 4: Share in 0ccupational Wage Categories by Gender \& Hourly Wage

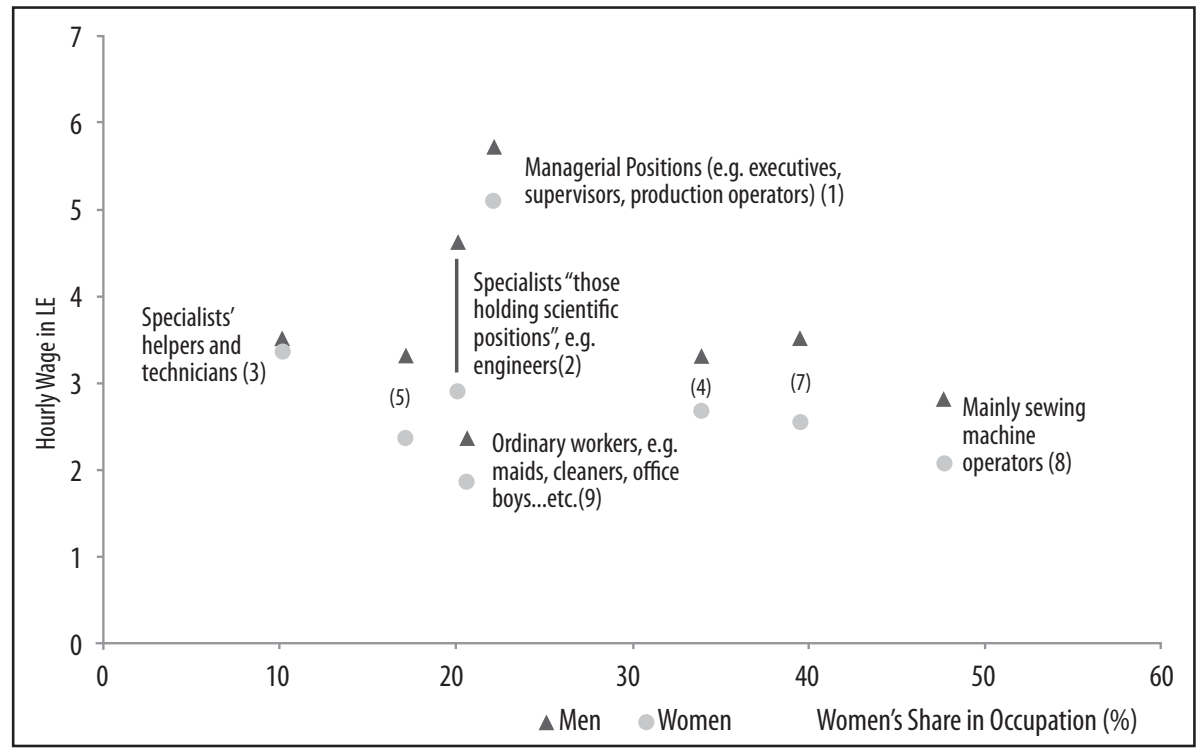

Source: Author's calculations based on IDSC Worker Questionnaire, 2009. 
Table 9: Hourly Wages: Mean, Standard Deviation, and Frequency by Occupation and Gender

\begin{tabular}{|c|c|c|c|c|}
\hline \multicolumn{2}{|l|}{ Occupation } & Men & Women & Total \\
\hline \multirow{2}{*}{$\begin{array}{l}\text { Managerial Positions (e.g. executives, } \\
\text { supervisors, production operators) (1) }\end{array}$} & Hourly Wages in LE & 5.76 & 5.1 & 5.61 \\
\hline & SD & 3.21 & 1.78 & 2.96 \\
\hline Frequency & & 183 & 52 & 235 \\
\hline \multirow{2}{*}{$\begin{array}{l}\text { Specialists ("those holding scientific } \\
\text { positions", e.g. engineers( (2) }\end{array}$} & Hourly Wages in LE & 4.69 & 2.9 & 4.33 \\
\hline & SD & 3.23 & 1.33 & 3.04 \\
\hline Frequency & & 239 & 60 & 299 \\
\hline \multirow{2}{*}{$\begin{array}{l}\text { Specialistss helpers and } \\
\text { technicians(3) }\end{array}$} & Hourly Wages in LE & 3.49 & 3.36 & 3.48 \\
\hline & SD & 1.84 & 2.02 & 1.86 \\
\hline Frequency & & 444 & 50 & 494 \\
\hline \multirow{2}{*}{ Office administrative positions (4) } & Hourly Wages in LE & 3.32 & 2.68 & 3.1 \\
\hline & SD & 1.91 & 0.99 & 1.68 \\
\hline Frequency & & 154 & 79 & 233 \\
\hline \multirow{2}{*}{$\begin{array}{l}\text { Workers in services, in shops and } \\
\text { markets(e.g. sellers of clothing) (5) }\end{array}$} & Hourly Wages in LE & 3.33 & 2.37 & 3.16 \\
\hline & SD & 1.46 & 0.41 & 1.38 \\
\hline Frequency & & 29 & 6 & 35 \\
\hline \multirow{2}{*}{ Handicraftsmen (7) } & Hourly Wages in LE & 3.53 & 2.55 & 3.14 \\
\hline & SD & 1.99 & 1.23 & 1.8 \\
\hline Frequency & & 386 & 252 & 638 \\
\hline \multirow{2}{*}{$\begin{array}{l}\text { Factory workers, machinery workers } \\
\text { and assembly workers (8) }\end{array}$} & Hourly Wages in LE & 2.83 & 2.25 & 2.55 \\
\hline & SD & 1.17 & 0.9 & 1.09 \\
\hline Frequency & & 1519 & 1383 & 2902 \\
\hline \multirow{2}{*}{$\begin{array}{l}\text { Ordinary workers(e.g. maids, } \\
\text { cleaners, office boys...etc.) (9) }\end{array}$} & Hourly Wages in LE & 2.34 & 1.87 & 2.24 \\
\hline & SD & 0.9 & 0.72 & 0.89 \\
\hline Frequency & & 289 & 75 & 364 \\
\hline \multirow{3}{*}{ Total } & & 3.29 & 2.42 & 2.96 \\
\hline & & 1.97 & 1.15 & 1.76 \\
\hline & & 3243 & 1957 & 5200 \\
\hline
\end{tabular}

Source: Author's calculations based on IDSC Worker Questionnaire, 2009. Note on occupational codes as in Table 7 above. 


\subsubsection{Sample Gender and Wage Distribution by Firm Characteristics}

Exporting firms hire relatively more women (Table ro: $41 \%$ ) compared to non-exporting firms $(34 \%)$. These firms also have a lower hourly wage gap: the gap is LE2.32 for non- exporting firms but only 67 piasters for exporting firms, i.e. one third of that of non-exporting firms (Table II). This finding is consistent with evidence from India showing that the wage gap is less in sectors with a greater export orientation (Reilly and Dutta, 2005).Using German firm-level data, Heinze and Wolf (2009) also find a smaller wage gap in firms that export more. Assaad has even spoken of a "reverse wage gap" in export sectors which heavily demand female labor (Population Reference Bureau 2008). However, this is not a universal rule, as Seguino reported a persistent wage gap despite substantial export growth in South Korea (1997), the same being argued for East Asia in general by Zveglich and Rodgers (2004).

With respect to size, the pay gap is wider in medium and large firms compared to small firms (Table I2). But larger firms also pay higher wages, so in absolute terms both men and women are better paid in these firms (this is of course before controlling for characteristics).

Table 10: Distribution of Employees by Firms'Market Orientation

\begin{tabular}{|l|c|c|c|}
\hline \multirow{3}{*}{ Non-exporting } & Men & Women & Total \\
\hline \multirow{3}{*}{ Exporting } & 1,597 & 829 & 2,426 \\
\cline { 2 - 4 } & $66 \%$ & $34 \%$ & $100 \%$ \\
\hline \multirow{2}{*}{ Total } & 1,646 & 1,128 & 2,774 \\
\cline { 2 - 4 } & $59 \%$ & $41 \%$ & $100 \%$ \\
\hline
\end{tabular}

Source: Author's calculations based on IDSC Worker Questionnaire, 2009. Note on occupational codes as in Table 7 above.

Table 11: Mean Hourly Wage by Gender and Firms' Market Orientation (in LE)

\begin{tabular}{|l|c|c|c|}
\hline & Men & Women & Hourly Wage Gap \\
\hline Non-Exporting & 4.87 & 2.55 & 2.32 \\
\hline Exporting & 3.57 & 2.9 & 0.67 \\
\hline
\end{tabular}

Source: Author's calculations. Sampling weights used. 
Table 12: Mean Gender Hourly Wage Gap by Firm Size (in LE)

\begin{tabular}{|l|c|c|c|}
\hline & Men & Women & Hourly Wage Gap \\
\hline Small: $0 \leq 50$ worker & 2.81 & 2.22 & 0.59 \\
\hline Medium: $50 \leq 150$ & 3.6 & 2.47 & 1.13 \\
\hline Large $>150$ & 3.99 & 2.95 & 1.04 \\
\hline
\end{tabular}

Source: Author's calculations. Sampling weights used.

\subsubsection{Employer's Gender Preference}

When asked if they preferred a particular gender to work in their firm provided both had the same educational attainment and skill level, $35 \%$ of employers (97 employers of a total of 275 ) stated that they do. Of these, over a half claimed they prefer men $(54 \%)$ the top reason being the difficulty of the task required of them ( $25 \%$ of those who prefer men), the second reason being men's lower rate of absenteeism $(22 \%)$.

When asked whether the average monthly wage differs between men and women who possess the same level of education and years of experience and are in the same occupation, only $16 \%$ of all employers agreed that it does. Nearly all of these respondents argued the preference was in favor of men $(96 \%)$. Again, the difference in tasks required of each sex topped the list of reasons for the difference ( 34 firms, $76 \%$ of these firms) followed by higher productivity for men (I9 firms, $42 \%$ ) and then the lesser number of hours worked per month by women compared to men ( 17 firms, $38 \%$ ), and finally female workers taking more leave (I2 firms, 27\%).

The following analysis will control for difference in worker and firm characteristics between men and women in order to judge the source of pay differences between them.

\subsection{Background}

Gender pay discrimination has been tackled theoretically via two distinct methodologies: direct and indirect. Following Oaxaca (I973), traditional wage equations can be decomposed to show how differences in wages can be attributed to differences in personal attributes or skills, plus discrimination due to gender-differentiated returns to those characteristics, and a residual pure discrimination effect.

This approach has been criticized for suffering from selection bias as it does not control for selection of labor market participants into the labor force and into the sectors and occupations they currently hold. Precisely, exclusion of non-participants in the labor force from the OLS wage regression equation, provided the participation decision is systematic, 
renders the pool of studied employees non-random and accordingly, results in biased estimates (Heckman I979; Maddala I983). This problem can be overcome by performing a double selection model (Heckman I979; Maddala 1983) where a further correction term for selection - calculated from a first stage participation equation - is added as a regressor to the earnings or the wage equation (cf. El-Hamidi and Said, 2008). The Oaxaca approach has also been criticized as the OLS residuals in the wage equations are assumed to have zero means, however, the expectation of the error term at a given quantile (along the wage distribution) need not be zero. Approaches analyzing gender wage discrimination at quantiles include that introduced by Gardeazabel and Ugidos (2005). Kandil (2009) has applied this technique to explore changes in the gender wage gap at the aggregate level in Egypt over three years (1988, 1998 and 2006). Rica et al. (2003) also explored the Spanish gender wage gap utilizing a quantile analysis.

The traditional Oaxaca-Blinder approach has increasingly been replaced by other methods. First, an analysis of whether discrimination is evident within the same establishment or firm utilizing a range of models, such as multilevel modeling and random effects on matched employer employee data (cf. Peterson and Morgan 1995; Groshen I991; Cardoso 2000; Gupta and Rothstein 200I; Meyersson-Milgrom et al. 200I; Bayrad 2003; Korkeamäki and Kyyrä 2005; Ilkkaracan and Selim 2007; Heinze and Wolf 2009). However, these studies are limited in number due to their demanding data requirements, there being only a handful of such studies even for the U.S. (Council of Economic Advisers, 1998) though this has been recently changing. The second approach measures male versus female productivity in order to link differences in pay to productivity. This approach is rarely implemented because of its even greater data requirements.

Indirect methodologies have most usually been applied in developed country research. This approach utilizes (field) experiments to prove discrimination by, for instance, sending out identical resumes with male and female names as job applications and thus discovering discrimination (cf. Petit 2007; see also same methodology applied to racial discrimination: Pager, Western, and Bonikowski 2009). A field experiment in the U.S. has been conducted by concealing the identity of symphony orchestra candidates from their audition juries. As a result chances of hiring female musicians have noticeably increased in such competitions (ibid.). Other studies have undertaken laboratory experiments (e.g. Andreoni and Petrie 2008). 


\subsection{Methodology}

The analysis proceeds in two stages. First, log hourly wages are estimated for both men and women using the classical least squares model. Second, a traditional Oaxaca-Blinder decomposition is performed based on these estimates. Oaxaca decomposition reveals whether differences in pay between men and women are due to differing characteristics between them or alternatively, due to discrimination (unjustified difference). Discrimination is present if pay differs for men and women with the same characteristics. The novel aspect of this analysis is that it combines both worker and firm data sets and hence, controlling for personal worker attributes but also firm and occupational attributes. Controlling for the latter is expected to reduce the discrimination effect although it may introduce other types of discrimination; that is, discrimination at the entry point for the various sectors of the economy, occupations within any one sector, and into particular types of firms. As a sectoral study, this study is able to quantitatively identify segregation or entry barriers of women to the last two, i.e. to certain firms and to certain occupations within a certain sector (here TC) but not into sectors, such as agriculture, industry or services, and then into subsectors within these (e.g. food industry, textiles and clothing, chemicals...etc.). Due to lack of data, performing a Heckman double selection correction model to control for selection into the labor force and into sectors is not possible. Controlling for self-selection depends on women's opportunity cost of time, and so will usually depend on a woman's family social background, her unearned income (or that of her household), her household's assets, and the employment status of males in her household. All these household-related variables are unfortunately unavailable in the datasets at hand. Nevertheless, at least selection into occupations within TC will be performed as a further extension to the paper at hand.

\subsubsection{Mathematical Representation}

Discrimination against women in the labor market exists when the ratio of the mean male and female wages does not equal the wage ratio in the absence of discrimination: WmWf $\neq \mathrm{WmoWf}$, where WmoWf is the ratio in the absence of discrimination, and WmWf is the observed male/female ratio (Oaxaca 1973). However, WmoWf is unobserved and so the observed wage difference is decomposed into two parts: a difference based on individual productivity traits (justified difference) and a difference based on market returns to those traits (unjustified difference or discrimination) (Borjas and Ramey, 2000).

Thus, for the purposes of estimating the male-female wage differential, the population regression line is given by: 
Where:

lnwi = logarithmic hourly wage

xii $=$ vector of worker personal attributes

$\mathrm{x} 2 \mathrm{i}=$ vector of firm and occupation attributes

$\mathrm{i}=\mathrm{m}$ for male workers, $\mathrm{f}$ for female workers

$\beta_{\mathrm{ji}}=$ associated vector of coefficients

$\mathrm{j} \quad=\mathrm{I}, 2$

$\varepsilon i=$ additive error term

The vector of worker personal attributes includes age, age squared, marital status and education level. Firm attributes include firm size, its market orientation, be it exporting or not, years of experience required by the firm for that particular occupation, and firm location (given by governorate) to control for differences in living standards across regions. An ownership variable to explore the possibility of different wages between Egyptian and foreign firms is also added to this vector.

The fitted lines take the following form:

$$
\begin{aligned}
& l n w_{m}=b_{0 m}+b_{1 m} \bar{x}_{1 m}+b_{2 m} \bar{x}_{2 m} \\
& l n w_{f}=b_{0 f}+b_{1 f} \bar{x}_{1 f}+b_{2 f} \bar{x}_{2 m}
\end{aligned}
$$

\section{Decomposition Analysis}

Mean difference between male and female wages is given by the following difference equation, which is the subtraction of equation (3) from (2):

$$
\begin{aligned}
& \Delta \ln \bar{W}=\ln \bar{W}_{m}-\ln \bar{W}_{f} \\
& \Delta l n \bar{W}=\left(b_{0 m}-b_{0 f}\right)+b_{1 m} \bar{x}_{1 m}+b_{1 m} \bar{x}_{1 f}-b_{1 m} \bar{x}_{1 f}-b_{1 f} \bar{x}_{1 f}+b_{2 m} \bar{x}_{2 m}+b_{2 m} \bar{x}_{2 f}
\end{aligned}
$$

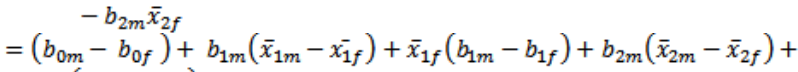

$$
\begin{aligned}
& \bar{x}_{2 f}\left(b_{2 m}-b_{2 f}\right) \\
& \text { (5) }
\end{aligned}
$$

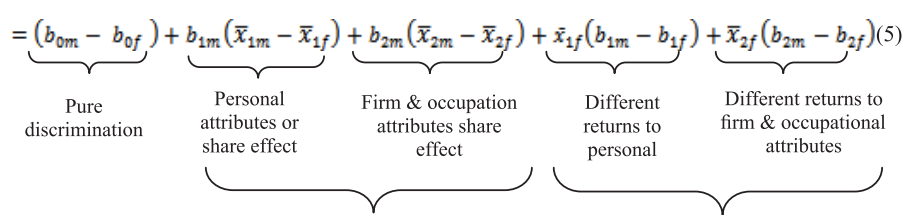

$$
\begin{aligned}
& \text { Allocation or share effect Different returns to characteristics }
\end{aligned}
$$

The second and third terms of equation (5) capture the allocation or share effect attributing part of the gender gap to difference in endowments 
between sample men and women. Endowments range from personal attributes (i.e. age, marital status and education level) to firm attributes (i.e. size, export status, required years of experience and ownership) and type of occupation workers are allocated to (i.e. ranging from occupations i to 9 as listed above). The last two terms of the equation capture discrimination or difference in returns to endowments between male and female workers. Finally, the first term signifies pure or outright discrimination between men and women, that is, the wage gap between men and women having allowed for their different characteristics and returns to those characteristics.

\section{Results}

\subsection{Wage Equation Regression Results}

Table I 3 presents regression results from 4 different specifications. Each specification is presented three times: on the pooled data set, and separately for men and women. The pure discrimination term (the coefficient on the sex variable in the pooled regression) is robustly significant, with a fairly stable coefficient across specifications. However it is lower in more fully specified models (regressions (3) and (4)) which include additional firm characteristics such as size, so papers ignoring those characteristics may overstate discrimination within firms.

\subsubsection{0ccupational Characteristics}

Log hourly wages for most categories are quite similar once characteristics such as education are controlled for. However, two occupational categories depart from this norm. Managers (occupation category $(\mathrm{I}))$ receive significantly higher wages compared to the reference category (occupation category $(5)$ : workers in services, in shops and markets, e.g. sellers of clothing) and office boys/girls (occupation category (9): ordinary positions) receive significantly less. In addition the "management premium" is quite a bit higher for women than men, i.e. compared to men women receive a larger incremental rise in hourly wages when climbing up the occupation structure from occupational category (5) to (I).

\subsubsection{Personal Attributes}

Significant increases in hourly wages accrue to both males and females as they attain more advanced stages of education, namely secondary and post-secondary education, and university and post-university education, though the incremental increase is slightly lower for women employees. The coefficient on age is highly significant and stable. With sample mean 
age for males of 36 years and of only 28 for their female counterparts, it is expected that the share or endowment effect will be substantial for this regressor.

Although not significant, it is worth noting that marital status is positive for men and negative for women. This may be due to differences in productivity levels. It is customary that women in Egypt are motivated, efficient and productive before marriage but that this changes with marriage and children. In relatively male dominated societies such as Egypt, working women are still expected to carry out all household responsibilities, hence crippling their performance at work, which in turn exercises downward pressure on their wages. At the extreme, once married, most women in this sector do not desire to work any longer or feel that they will be unable to do so (Assaad and El Hamidi 2009). This is because most of the female workers in the sector are young, unmarried ${ }^{3}$ secondary school graduates who still live with their parents. Their main reason to work is to prepare themselves for marriage and to financially assist their parents (ibid.), with marriage this reason no longer holds. In Islamic societies men are expected to financially provide for the family. Hence, another explanation for the opposing signs for the coefficient on marital status may be employers' belief that married men need more money than unmarried women.

\subsubsection{Firm Attributes}

Despite a lower gender pay wage gap in exporting firms (see Sample Descriptives section above), wages in these firms are significantly lower than those in non-exporting firms once characteristics are controlled for. All characteristics' hourly wages are significantly lower for employees of exporting firms compared to non-exporters. ${ }^{4}$ The difference in wages between exporters and non-exporters is larger for men than it is for women. Producers for the domestic market compete with each other but in a still largely protected market, ${ }^{5}$ but exporting firms compete in alargely competitive international market and so hourly wages reflect this fact. Exporters have been divided into qualifying industrial zones (QIZ) exporters and non-QIZ ones, but the results are essentially the same and

3 As shown by the means of these variables presented earlier.

4 This slightly contradicts the findings of Al Azzawi and Said (2009) that wages in industries with a higher share of exports are higher.

5 This is because most favored nation tariff (MFN) rates on the imports of TC are non-zero. Currently MFN tariffs on yarns range between $0-5 \%$, fabrics $0-10 \%$ and tariffs on carpets and other textile floor coverings, clothes and home textiles are generally in the neighborhood of 30\% (Presidential Decrees 2000, 2004 and 2007). These rates are in full accordance with Egypt's WTO commitments. Indeed, in most cases these rates are below their WTO bound rates (El-Haddad 2010). 
the F-test allows the combination of these categories into one (that is exporting, see more elaborate specifications in Annex I).

Adding firm size substantially improves the results (regressions 3 and 4). Regression 3 uses size as a categorical variable whilst regression 4 uses dummies for three firm sizes: small ( $0<50$ workers), medium ( $50 \leq$ I50 workers) and large (>150 workers) since the categories could not be combined according to an $\mathrm{F}$ test. Medium sized firms pay higher wages in general (log LE O.I333 higher than small firms), and larger firms pay even higher ( 0.272 higher). However, for women the incremental increase is much higher for large firms compared to medium ones (regression (4): 0.238 compared to only 0.075 ). The ownership variable is never significant, possibly due to multicollinearity with the export and size variables. This, together with the joint F-test, makes regression (4) the best specification for this data set. Experience dummies have the right signs but are almost always significant for men but not for women, most likely as just under $90 \%(87 \%)$ of women join firms and occupations that require little or no experience compared to $78 \%$ for men. ${ }^{6}$ Alexandria governorate pays significantly lower wages compared to Al Sharkeya, the reference category, but also compared to Greater Cairo.

6 This is because tasks like sewing, where women are concentrated, need less training. 


\begin{tabular}{|c|c|c|c|c|c|}
\hline$\$ \tilde{z}$ & 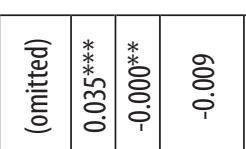 & 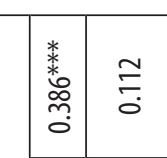 & $\bar{s}$ & 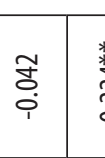 & \\
\hline & 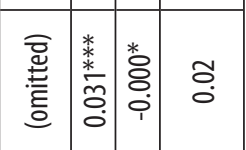 & \begin{tabular}{|l|l}
$\frac{\alpha}{3}$ \\
\end{tabular} & $\overline{\mathrm{z}}$ & 惫 & \\
\hline & 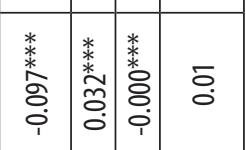 & \begin{tabular}{|l|l}
$\frac{5}{2}$ \\
$\frac{5}{3}$
\end{tabular} & 言 & 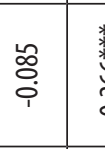 & \\
\hline & 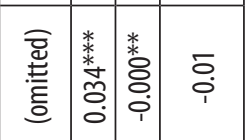 & \begin{tabular}{|l|l}
$\frac{5}{3}$ & $\frac{2}{3}$ \\
\end{tabular} & : & 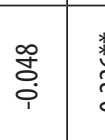 & \\
\hline & 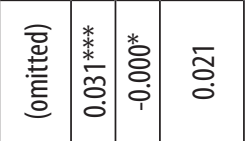 & $\frac{5}{3}$ & $\overline{\bar{z}}$ & \begin{tabular}{l|l}
$\frac{1}{3}$ & $\frac{1}{3}$ \\
3
\end{tabular} & \\
\hline & 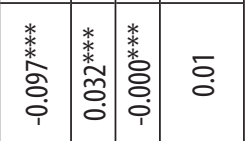 & \begin{tabular}{|l|l}
$\frac{5}{3}$ \\
$\frac{5}{3}$
\end{tabular} & : & 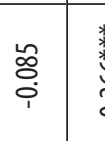 & \\
\hline & 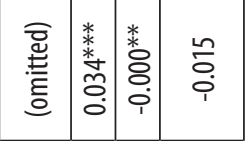 & 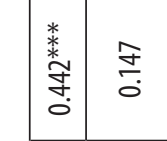 & 害 & 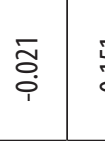 & \\
\hline & 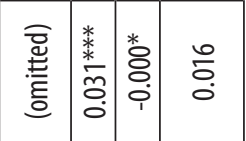 & $\frac{2}{8}$ & : & 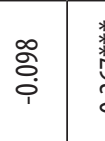 & \\
\hline & 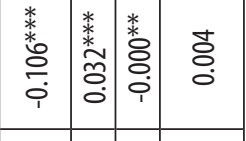 & 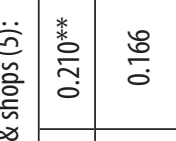 & $\frac{\circ}{5}$ & $\frac{1}{3}$ & \\
\hline & 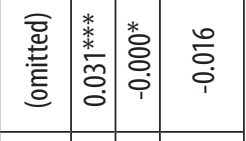 & 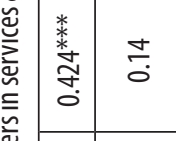 & 咢 & 蒡 & \\
\hline & 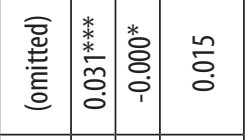 & 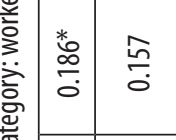 & 喜 & \$: & \\
\hline & 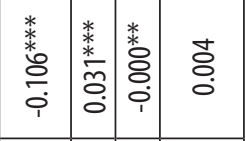 & 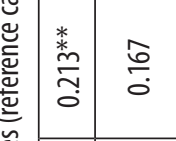 & $\frac{\circ}{\partial}$ & : & 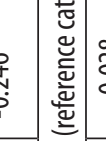 \\
\hline & 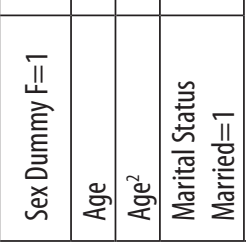 & & & & \\
\hline
\end{tabular}




\begin{tabular}{|c|c|c|c|c|c|c|c|c|c|c|c|c|c|c|c|c|c|c|c|}
\hline \multirow{3}{*}{ 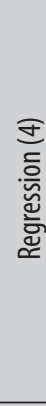 } & 3 & $\begin{array}{l}\text { 委 } \\
\text { o. } \\
0 \\
0\end{array}$ & & 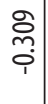 & $\begin{array}{c}\tilde{c} \\
\hat{i} \\
\end{array}$ & 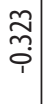 & t. & 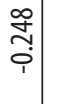 & & 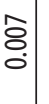 & $\begin{array}{l}\text { 苂 } \\
\stackrel{8}{0} \\
\stackrel{i}{1}\end{array}$ & & & $\begin{array}{l}\underset{\Xi}{ \pm} \\
\text { i. }\end{array}$ & & & & & 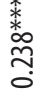 \\
\hline & $\sum$ & 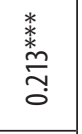 & & $\begin{array}{l}\text { 类 } \\
\\
\\
\\
\end{array}$ & 兮 & 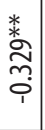 & 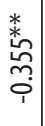 & 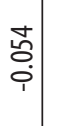 & & 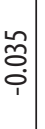 & 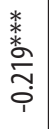 & & & $\begin{array}{l}\text { 粪 } \\
\stackrel{o}{0} \\
\\
\end{array}$ & & & & & $\begin{array}{l}\text { 类 } \\
\text { 今े } \\
\text { Oे }\end{array}$ \\
\hline & 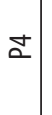 & \begin{tabular}{l} 
* \\
\multirow{2}{N}{} \\
0
\end{tabular} & & 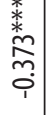 & 菅 & 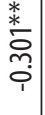 & 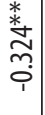 & $\begin{array}{l}\tilde{m} \\
\hat{o} \\
\hat{i} \\
\end{array}$ & & $\begin{array}{l}\bar{o} \\
\bar{i} \\
i\end{array}$ & 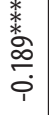 & & & $\begin{array}{l}\text { 类 } \\
0 \\
0 \\
0 \\
0\end{array}$ & & & & & 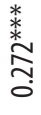 \\
\hline \multirow{3}{*}{ 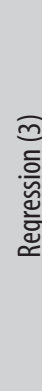 } & 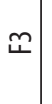 & $\begin{array}{l}\text { 系 } \\
\text { 怘 } \\
0 \\
0\end{array}$ & & 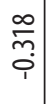 & 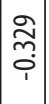 & 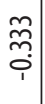 & \begin{tabular}{l}
$\tilde{z}$ \\
\multirow{7}{*}{} \\
$i$
\end{tabular} & 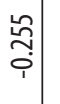 & & 会 & $\begin{array}{l}\text { 类 } \\
\text { Oे } \\
\text { i }\end{array}$ & & & $\begin{array}{l}\infty \\
\stackrel{\infty}{0} \\
\stackrel{\varphi}{1}\end{array}$ & 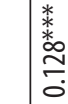 & & & & \\
\hline & $\sum$ & 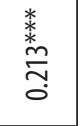 & & 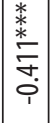 & 产 & 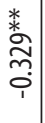 & 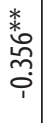 & $\begin{array}{l}2.2 \\
0 \\
0 \\
0\end{array}$ & & 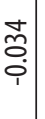 & 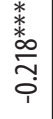 & & & $\begin{array}{l}\text { 粒 } \\
\stackrel{0}{0} \\
\end{array}$ & 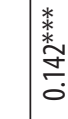 & & & & \\
\hline & $\cong$ & \begin{tabular}{l} 
w \\
\multirow{2}{N}{} \\
0
\end{tabular} & & 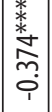 & $\mid \begin{array}{c}\infty \\
\stackrel{o}{0} \\
\grave{i} \\
\end{array}$ & 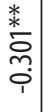 & 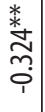 & $\begin{array}{l}\tilde{m} \\
\tilde{o} \\
\dot{i}\end{array}$ & & 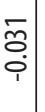 & $\begin{array}{l}\frac{*}{*} \\
\stackrel{6}{\circ} \\
\vdots \\
\end{array}$ & & & $\begin{array}{l}\text { 蔷 } \\
0 \\
0 \\
0 \\
\end{array}$ & 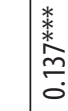 & & & & \\
\hline \multirow{3}{*}{ 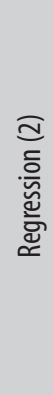 } & $\widetilde{\sim}$ & $\begin{array}{l}\text { 糙 } \\
\text { 员 }\end{array}$ & & 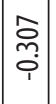 & $\begin{array}{c}\bar{D} \\
\bar{p} \\
\bar{i}\end{array}$ & 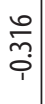 & \begin{tabular}{l}
$\approx$ \\
\multirow{7}{*}{} \\
$\stackrel{i}{i}$
\end{tabular} & $\begin{array}{l}\widetilde{\approx} \\
\stackrel{i}{0}\end{array}$ & & 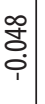 & 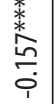 & & & $\begin{array}{l}\text { 䊝 } \\
o \\
0 \\
0\end{array}$ & & & & & \\
\hline & $\tilde{\Sigma}$ & \begin{tabular}{l} 
* \\
\multirow{2}{\pm}{} \\
$\vdots$ \\
0
\end{tabular} & & 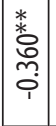 & 它 & 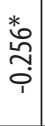 & 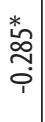 & ఫ̊요 & & 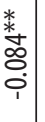 & 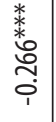 & & & $\begin{array}{l}\text { o̊ } \\
\text { co }\end{array}$ & & & & & \\
\hline & $\approx$ & 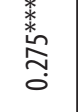 & 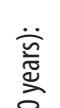 & 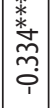 & 容 & 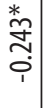 & 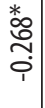 & $\begin{array}{l}0 \\
\vdots \\
0 \\
0\end{array}$ & & 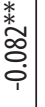 & \begin{tabular}{l} 
悉 \\
\multirow{7}{*}{} \\
$\stackrel{i}{i}$
\end{tabular} & & & $\grave{\delta}_{0}^{m}$ & & & & & \\
\hline \multirow{4}{*}{ 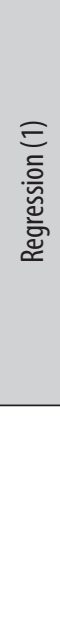 } & $\bar{\square}$ & $\begin{array}{l}\text { 桊 } \\
\text { O } \\
0 \\
0\end{array}$ & $\begin{array}{l}\text { 言 } \\
\text { 离 }\end{array}$ & $\begin{array}{c}\overline{\tilde{m}} \\
\bar{i} \\
\bar{i}\end{array}$ & 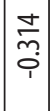 & 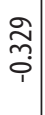 & 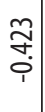 & $\begin{array}{l}\underset{\Xi}{\Xi} \\
\vdots\end{array}$ & 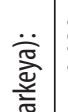 & 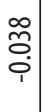 & 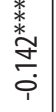 & & & & & & & & \\
\hline & $\bar{\Sigma}$ & 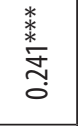 & 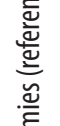 & 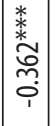 & $\begin{array}{c}\bar{f} \\
\dot{Q} \\
\bar{i}\end{array}$ & 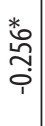 & 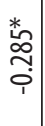 & 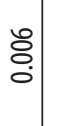 & 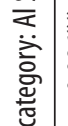 & 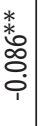 & 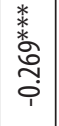 & & & & & & & & \\
\hline & $\bar{a}$ & 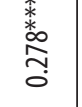 & 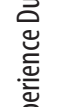 & 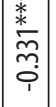 & 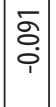 & 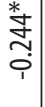 & 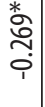 & $\begin{array}{l}\overline{0} \\
\vdots \\
0\end{array}$ & 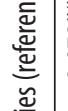 & 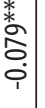 & 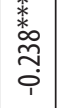 & &.$\overline{\underline{\underline{\Xi}}}$ & & & & & & \\
\hline & & 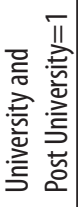 & 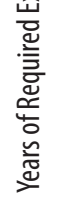 & 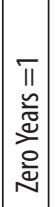 & 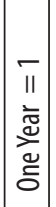 & 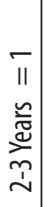 & 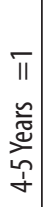 & 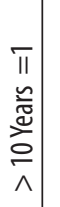 & 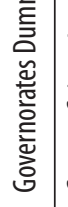 & 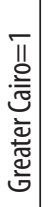 & 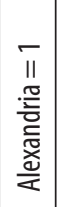 & 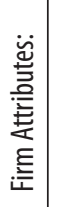 & 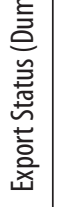 & 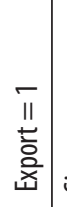 & 吾 & $\begin{array}{l}\sim \\
\pi \\
0 \\
0 \\
v 1 \\
\text { vin } \\
i n\end{array}$ & $\begin{array}{l}n \\
11 \\
0 \\
0 \\
\wedge\end{array}$ & $\begin{array}{l}-\pi \\
11 \\
0 \\
\frac{n}{2} \\
\text { VI } \\
i n\end{array}$ & 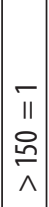 \\
\hline
\end{tabular}




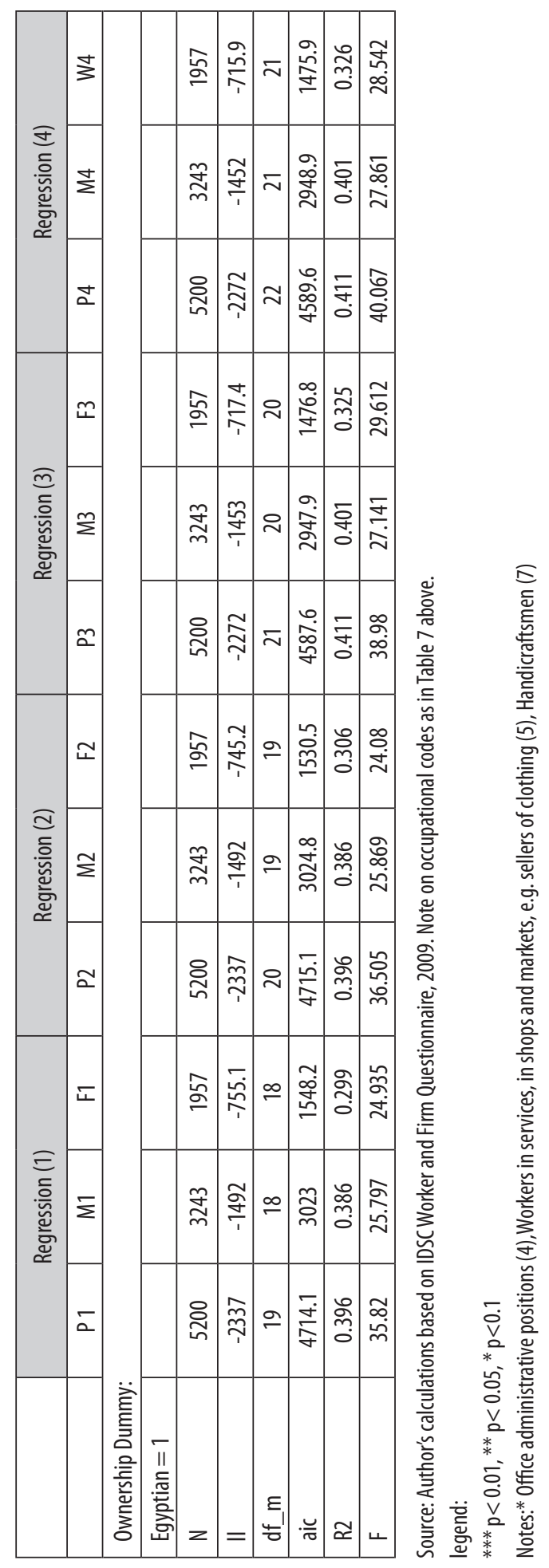




\subsection{Decomposition Results}

In the TC industry women receive $22 \%$ lower log hourly wages than men, in other words they receive only $78 \%$ of the hourly wage men receive in the industry. ${ }^{7}$ A substantial part of this gap $\left.{ }_{72} \%\right)$ is explained by differences in women's personal endowments compared to men's (Figure 5); sampled women are relatively younger and less educated than men in the sample (refer to Annex 2 for descriptives of all regression variables).

One-fifth of the gap (19\%) is attributable to women being employed in low paying firms and occupations; those requiring little or no experience (see preceding section above). and to them being relegated to exporting; smaller sized firms, where everyone makes less money. The concentration of females in these types of firms and occupations could also be regarded as "indirect or concealed discrimination," but at the entry point. Even though such entry barriers are justified by endowments, it is these endowments that constitute what Roemer (1998) calls "inequality of opportunity" which are [partly] created by what he calls "circumstances," such as racial and family background, which the individual should not be held accountable for from a social justice perspective. Hence, it is the endowments that need to be enhanced for females in the sector to climb to the top of the occupational ladder. Two factors, namely females' personal attributes and their allocation to low paying firms and occupations, together explain over $90 \%$ of the gap (Table I4). Note that the data set does not include information on "circumstances" and so cannot quantify how much of the endowments and allocation is due to "circumstances" and how much is due to "effort." Hence, further rigorous analysis is required.

Only $9 \%$ of the gap is attributable to discrimination. This low figure results from two counteracting tendencies. Women are actually favored in terms of returns to firms' characteristics and occupations, as well as personal characteristics. That is, women with the same characteristics as men receivehigher pay, and the intra-occupational pay gap is reversed once characteristics are controlled for (-0.I6 and-0.I7 log hourly LE respectively). Thus, outright discrimination is the sole reason for discrimination and could be partially explained by the difference between the role society expects of men and that it expects of women, the former being the main bread earner. This explanation is in line with the tradition of women's wages being "pin money," that is for women's own petty expenses. This view is not confined to Arab or Muslim societies. Evidence from OECD countries suggests that perceptions of women's role as homemakers, which are likely formed in youth and linked to religious ideology, have persisted

7 Note that this gap is expressed in log terms, the actual gap in absolute Egyptian pounds amounts to $29 \%$.

8 More precisely "effort" beyond an individual's group or type average effort level. This is so since Roemer divides individuals to types of similar circumstances (Roemer 1998). 
over time (Fortin 2005). Note that this is the perception of the employer as much as it is that of the woman herself, and her personal expectation of what (pay) she deserves. A study on Israeli men and women has shown that complacency regarding wages is more prevalent among more traditional and religious women than among "modern" women. The former turn to low status, female-typed occupations, and prefer to work in part-time jobs (Moore 2006). In developing Asia, particularly South Asia, gender gaps remain significant across the labor market. A recent survey of the empirical literature suggests this persistence of gender inequality is caused and reinforced by interlinked cultural, social, and economic factors (Nimii 2009). It could also be explained by a trend toward gender equality in which employers want to employ women, and since women are less qualified, end up giving equal pay to women who are less qualified than their male counterparts. However, there is not yet any equal pay legislation in force in Egypt. The plausibility of both these explanations requires further research.

Figure 5: Log Hourly Wage Gap Decomposition

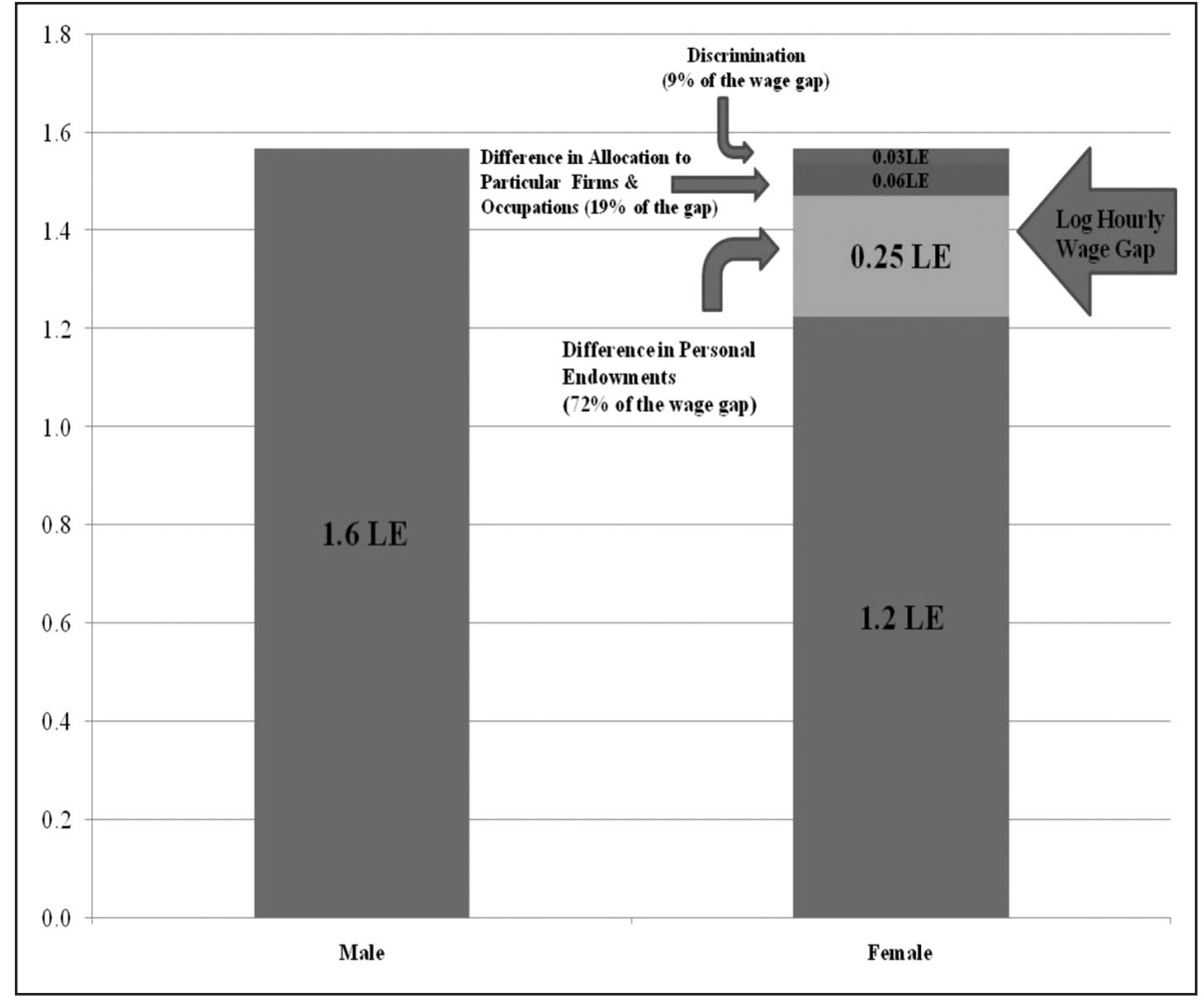

Source: Author's calculations based on IDSC Worker Questionnaire, 2009. 
Table 14: Full Decomposition of the Log Hourly Gender Gap ( $\left(\operatorname{lnw}_{\mathrm{m}}-\operatorname{Inw}_{\mathrm{f}}\right)$

\begin{tabular}{|l|c|c|}
\hline & in log LE & \% of Gap \\
\hline Discrimination & & \\
\hline Pure discrimination & 0.36 & $105 \%$ \\
\hline Difference in returns to personal characteristics & -0.16 & $-47 \%$ \\
\hline $\begin{array}{l}\text { Difference in returns to occupation and to firm } \\
\text { characteristics }\end{array}$ & -0.17 & $-48 \%$ \\
\hline Discrimination Total & 0.03 & $9 \%$ \\
\hline $\begin{array}{l}\text { Difference in Endowments } \\
\text { (in characteristics, firms and occupations) }\end{array}$ & & \\
\hline Personal attributes & 0.25 & $72 \%$ \\
\hline Occupational and firm attributes & 0.06 & $19 \%$ \\
\hline Endowment Total & 0.31 & $91 \%$ \\
\hline Total Hourly Wage Gap & 0.34 & $100 \%$ \\
\hline
\end{tabular}

Source: Author's calculations based on IDSC Worker Questionnaire, 2009.

\section{Conclusions}

There is a $29 \%$ gender wage gap in the textiles and clothing sector in Egypt. The analysis presented in this paper attributes the largest portion of this gap ( 72 percent) to differences in endowments between men and women. Most of the remaining gap (I9 percent) is accounted for by women's relegation to low paying occupations and lower-paying firms. In particular, there is a clear glass ceiling in effect, in which women are significantly under-represented in the highest-paying management positions.

Only 9 percent of the gap is explained by what is usually classified as discrimination. The differences in returns in fact favor women. That is, women with identical characteristics as men receive higher pay, and the intra-occupational pay gap is reversed once characteristics, including firm characteristics, are controlled for. Failure to control for firm characteristics, as in most studies as they do not use firm data, will over-estimate the gap. Outright discrimination is the sole reason for discrimination and could be partially explained by the difference between the role society expects of men and that it expects of women, the former being the main bread earner, but this argument requires further investigation.

However, discrimination plays a large role that this analysis suggests, since both endowments (lower education and experience) and women's allocation to low paying firms and occupations are indirect discrimination, but at the entry point. Even though such entry barriers are justified by 
endowments, it is these endowments that constitute what Roemer (1998) calls "inequality of opportunity" which are created by "circumstances", such as racial and family background, which the individual should not be held accountable for from a social justice perspective. There is thus a need for an "equal opportunity" policy to "level off the mounds and troughs in the playing field" (Roemer 1998, p.5). Since returns to characteristics favor females, concerted efforts to enhancing endowments may reverse the gender wage gap. Efforts such as Conditional Cash Transfers (CCTs) given to those parents who send their daughters to school in Upper Egypt are currently being applied and, if successful, could be scaled up to secondary and post-secondary education levels. CCTs have proven very successful in Bangladesh's Female Secondary School Assistance Project. Female enrolment rates have risen from $33 \%$ in I99I, the year the project was implemented, to $48 \%$ within six years of implementation and further to $56 \%$ in 2005. CCTs have generally also been very successful in Mexico. "Oportunidades" in Mexico aimed to break the cross-generational cycles of poverty; its success being followed by Brazil's "Bolsa Familia" in Brazil, and other schemes across Latin America.

In as much as the wage gap is explained by both outright discrimination and entry barriers, the gap can be narrowed by promoting labor standards, especially in the private sector. Men and women are equal under the Egyptian constitution. However, an equal pay act, ${ }^{9}$ ensuring equal pay for equal work, and which prohibits discrimination at the entry points into the labor market, in job titles, in job ranks and in pay scales, is yet to be passed. Egypt ratified the United Nations Convention on the Elimination of All Forms of Discrimination against Women (CEDAW) in I98I, and so is committed to ensuring equal treatment of men and women. Nevertheless, there is no mention of the prohibition of unequal treatment such as that specified, for example, in the Equal Pay Act of the United Kingdom. In the UK the Act was passed in 1970 , coming into force by the end of 1975 . The term "pay" is interpreted in a broad sense to include, on top of wages, things like holidays, pension rights, company benefits, and some kinds of bonuses in addition to "hiring." Once the law was passed, the judicial system began handling cases of complaint of unequal pay, becoming the main enforcement mechanism. What is integral to this process is that women are educated about their rights as given to them by law, and are at the same time granted protection from any possible harassment if they actually step forward.

9 The unified labor law of the year 2003 does indeed contain an article on the prohibition of wage discrimination based on gender (article 35). 
Passing an equal pay act, including prohibition of discrimination at labor market entry, in job titles, job ranks, and in pay scales according to sex is essential. Yet it is equally important to avoid excessive use of the law to impose social entitlements and fringe benefits for women. Such social burdens may negatively affect employers' incentives to create new female jobs (cf. Süral, 2009).

Gender inequality is greater when a country's economic opportunities are more limited and households are in greater economic hardship (Nimii, 2009). Hence, in agreement with Nimii (2009), along with efforts to remove cultural, social, and institutional obstacles through educating the public, introducing and enforcing antidiscrimination legislation, promoting economic development to generate economic opportunities and improving women's capabilities and access to these opportunities are key to greater progress toward gender equality and inclusive growth.

The novel aspect of this study is that it combines both worker and firm level data. But a caveat remains, calling for furtherwork. The decomposition does not control for selection of labor market participants into the sectors and occupations they are currently holding. Whilst the latter is doable with the dataset at hand it would still leave the problem of selection bias into the labor force, and then into the sector of employment, which is a twostep selection process. Modeling this stage requires information on the non-working (i.e. those outside the labor market). Thus, subsequent work will need to combine these data with additional data and use additional econometric techniques to tackle these issues. 


\section{References}

AlAzzawi, S. and Said, M., 2009. Trade liberalization, Inter-industry Wage Differentials and Job Quality in Egyptian Manufacturing. Gender and Work in the MENA Region Working Paper No. 6. Cairo: Population Council

Anderoni, J. and R. Petrie, 2008. Beauty, Gender and Stereotypes: Evidence from Laboratory Experiments, Fournal of Economic Psychology 29, pp. 73-93.

Assaad, R., and El-Hamidi, F., 2009. Women in the Egyptian Labor Market: An Analysis of Developments, 1988-2006. In: Assaad, R. (ed.). The Egyptian Labor Market Revisited. Cairo: American University in Cairo Press, pp. 219-255.

Bayrad, K., Hellersteind, J. Neumark, D., Troske, K., 2003. New evidence on sex segregation and sex differences in wages from matched employee-employer data. Fournal of Labor Economics 2I(4), pp. 887-922.

Borjas, G. J., and Ramey, V. A., 2000. Market Responses to Inter industry Wage Differentials, NBER Working Papers No. 7799. Cambridge, Massachusetts: National Bureau of Economic Research, Inc. (NBER).

Council of Economic Advisers, 1998. Explaining Trends in the Gender Wage Gap. Washington DC, USA: Council of Economic Advisers (CEA) White Paper

Cardoso, A. R., 2000. Wage Differentials across Firms: An Application of Multilevel Modeling. Fournal of Applied Econometrics, 15, pp. 343-354.

Central Agency for Public Mobilization and Statistics (CAPMAS), 2008. Annual Industrial Statistics. Cairo: Central Agency for Public Mobilization and Statistics, Various issues.

Datta Gupta, N. and Rothstein, D. S., 200I. The Impact of Worker and Establishment Level Characteristics on Male-Female Wage Differentials: Evidence from Danish Matched Employee-Employer Data. Centre for Labor Market and Social Research Working Paper 0I-09-200I. Aarhus: Centre for Labour Market and Social Research

De La Rica, S., 2003. Decomposing the Gender Wage Gap: The effects of Firm, Occupation and Job Stratification. UC Berkley Center for Labor Economics Working Paper No. 64. California: Center for Labor Economics, University of California Berkley.

El-Haddad, A., 2009. Labor MarketGender Discrimination under Structural Adjustment: The Case of Egypt.SRC/SIDA, Research Program on Gender and Work Working Paper, o03. Cairo: Social Research Center, American University in Cairo.

El-Haddad, A., 20ro. Effects of the Global Crisis on the Egyptian Textiles and 
Clothing Sector: A Blessing in Disguise? ECES Working Paper No. 156. Cairo: Egyptian Center for Economic Studies.

El-Hamidi, F. and Said, M., 2008. Have Economic Reforms Paid Off? Gender Occupation Inequality in the New Millennium in Egypt. ECES Working Paper No. I28. Cairo: Egyptian Center for Economic Studies.

Gardeazabel, J. and Ugidos, A. 2005. Gender Wage Discrimination at Quantiles, Fournal of Population Economics, I8, pp. 165-179

Groshen, E. L., I991. The Structure of the Female/Male Wage Differentials: Is it Who You Are, What You Do o Where You Work?, Journal of Human Resources, 26 (3), pp. 457-472.

Heckman, J. 1979. Sample Selection Bias as a Specification Error, Econometrica, 47, pp. 153-6I.

Heinze, A. and Wolf, E., 2009.The Intra-firm Gender Wage Gap: A New View on Wage Differentials Based on Linked Employer-Employee Data, Fournal of Population Economics, 23 (3), pp. 85 $\mathrm{I}^{-8} 89$.

Ilkkaracan, I. and Selim, R., 2007. The Gender Wage Gap in the Turkish Labor Market. Labor, 2I(3), pp. 563-593.

Industrial Development Authority (IDA). 2009 IDA Online Database. Cairo: Industrial Development Authority. Available online at: http://www. ida.gov.eg/Egmaly_en.html [Accessed 4 June 2009]

International Trade Centre. 2008. International Trade Map Online Database. Geneva: International Trade Centre UNCTAD/WTO (ITC). Available online at: http://www.trademap.org/ [Accessed November 2008]

Kandil, L., 2009.Gender Wage Discrimination in Egypt: A 2uantile Regression Analysis. Paris: Université Paris I Panthéon-Sorbonne.

Korkeamäki, O. and Kyyrä, T., 2005. A Gender Wage Gap Decomposition for Matched Employer-Employee Data, Labour Economics, I3, pp.611-638.

Madalla, G.S., 1983. Limited-Dependent Variables and 2ualitative Variables in Econometrics. Cambridge: Cambridge University Press.

Ministry of State for Economic Development. 2008. Follow-Up Report for the Year 2007/2008. Cairo: Ministry of State for Economic Development.

Moore, D. 2006. Why Don't They Demand More? Entitlement and Work Values of Religious and Secular Women and Men in Israel, fournal of Applied Social Psychology 36(8), pp. 1924-1960.

Myersson Milgrom, E., Petersen, T. and Snartland, V., 200I. Equal Pay for Equal Work? Evidence from Sweden and a Comparison with Norway and the US, Scandinavian Fournal of Economics, $\mathrm{IO}_{3}$ (4), pp.559-583.

Nimii, Y. 2009. Gender Equality and Inclusive Growth in Developing Asia, Asian Development Bank Economics Working Paper Series I86.

Oaxaca, R. L., I973. Male Female Wage Differentials in Urban Labor Markets, International Economic Review, I4, pp.693-709. 
Pager, D., B. Western, and B. Bonikowski 2009. Discrimination in a Low-Wage Labor Market: A Field Experiment, American Sociological Review 74(5), pp. $777^{-799 .}$

Peterson, T., and Morgan, L., I995. Separate and Unequal: Occupation Establishment Sex Segregation and the Gender Wage Gap, American fournal of Sociology, IOI (2), pp.329-365.

Petit, P. 2007. The effects of age and family constraints on gender hiring discrimination: A field experiment in the French financial sector, Labor Economics I4(3), pp. 371-39I.

Population Reference Bureau, 2008. Interview with Ragui Assaad on The Middle East Youth Bulge: Causes and Consequences. Washington, DC: Population Reference Bureau. Available online at: < http://discuss. prb.org/content/interview/detail/2295/> [Accessed I5 June 20IO]

Presidential Decrees 429/2000, 300/2004, and 39/2007

Reilly, B. and Dutta, P. V., 2005. The Gender Pay Gap and Trade Liberalization: Evidence for India. PRUS Working Paper No. 32. Sussex: Poverty Research Unit at Sussex.

Roemer, 1998. Equality of Opportunity. Cambridge, Mass.: Harvard University Press.

Seguino, S., 1997. Gender wage inequality and export-led growth in South Korea. Fournal of Development Studies, 34 (2), pp.IO2-I32.

Süral, S., 2009. Anti-Discrimination Rules and Policies in Turkey. Comparative labor lawe and policy journal, 30, pp.245-272.

Zveglich Jr.,Y. E. and Van der Meulen Rodgers, Y., 2004. Occupational Segregation and the Gender Wage Gap in a Dynamic East Asian Economy, Southern Economic Fournal, 70. 


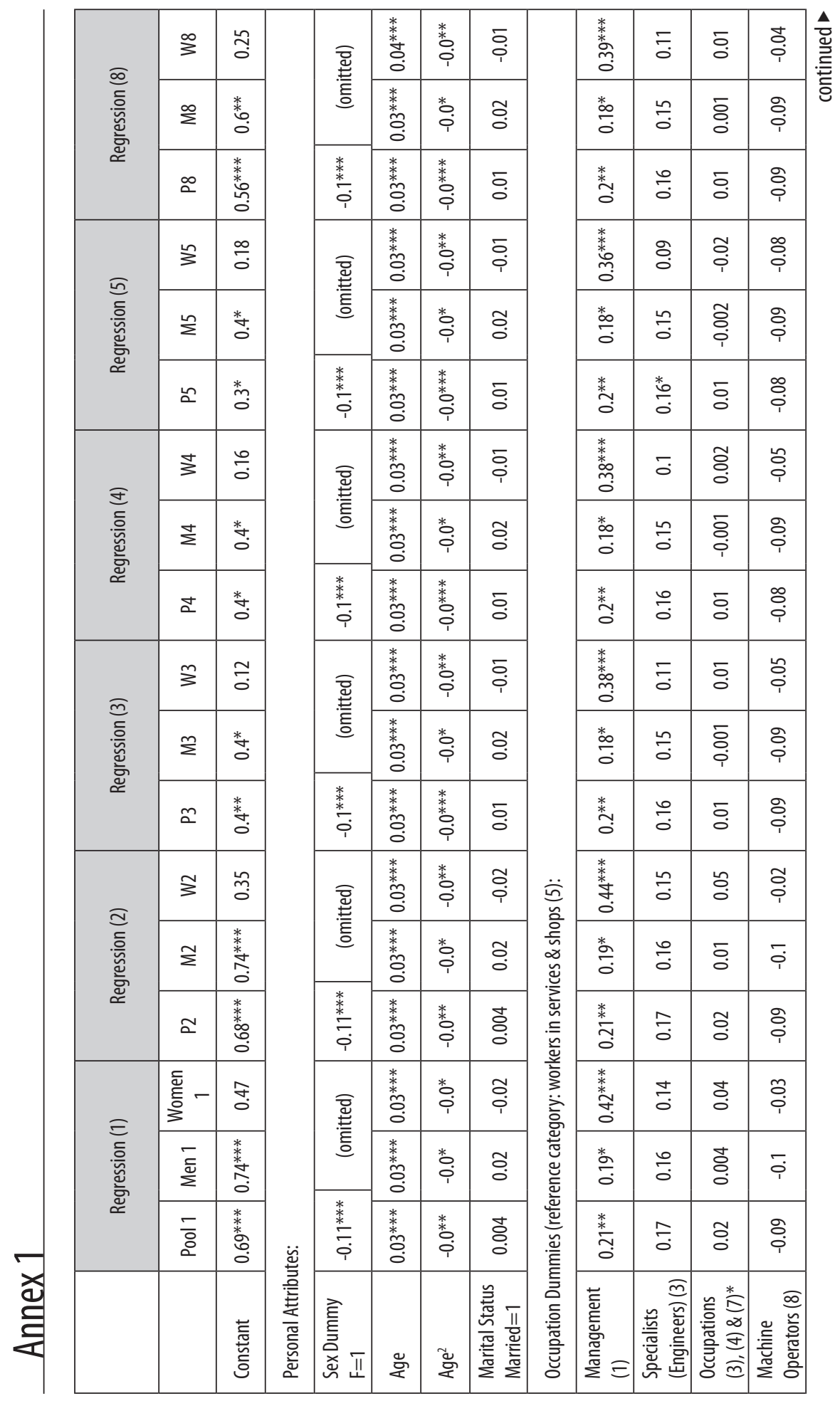




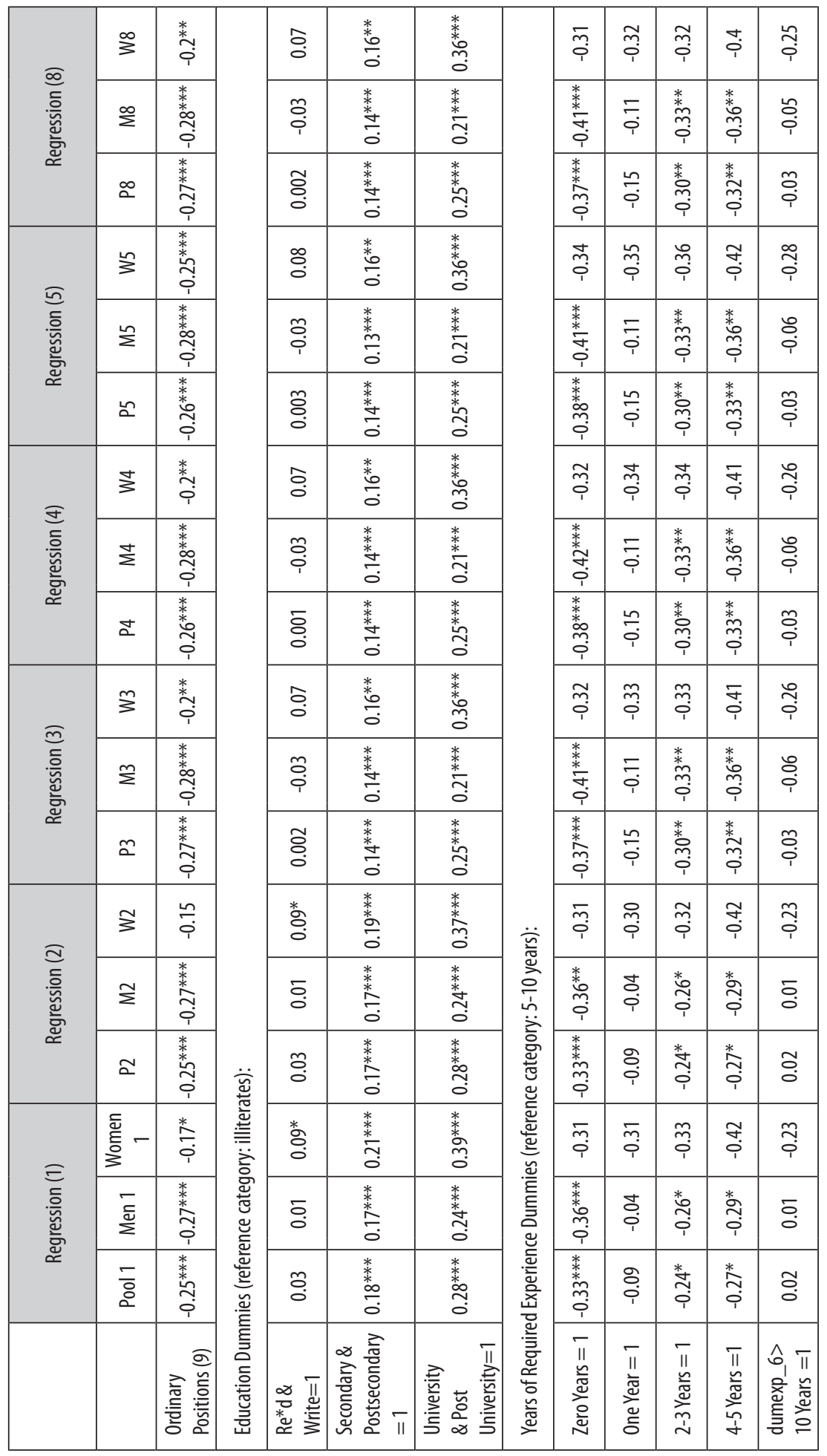




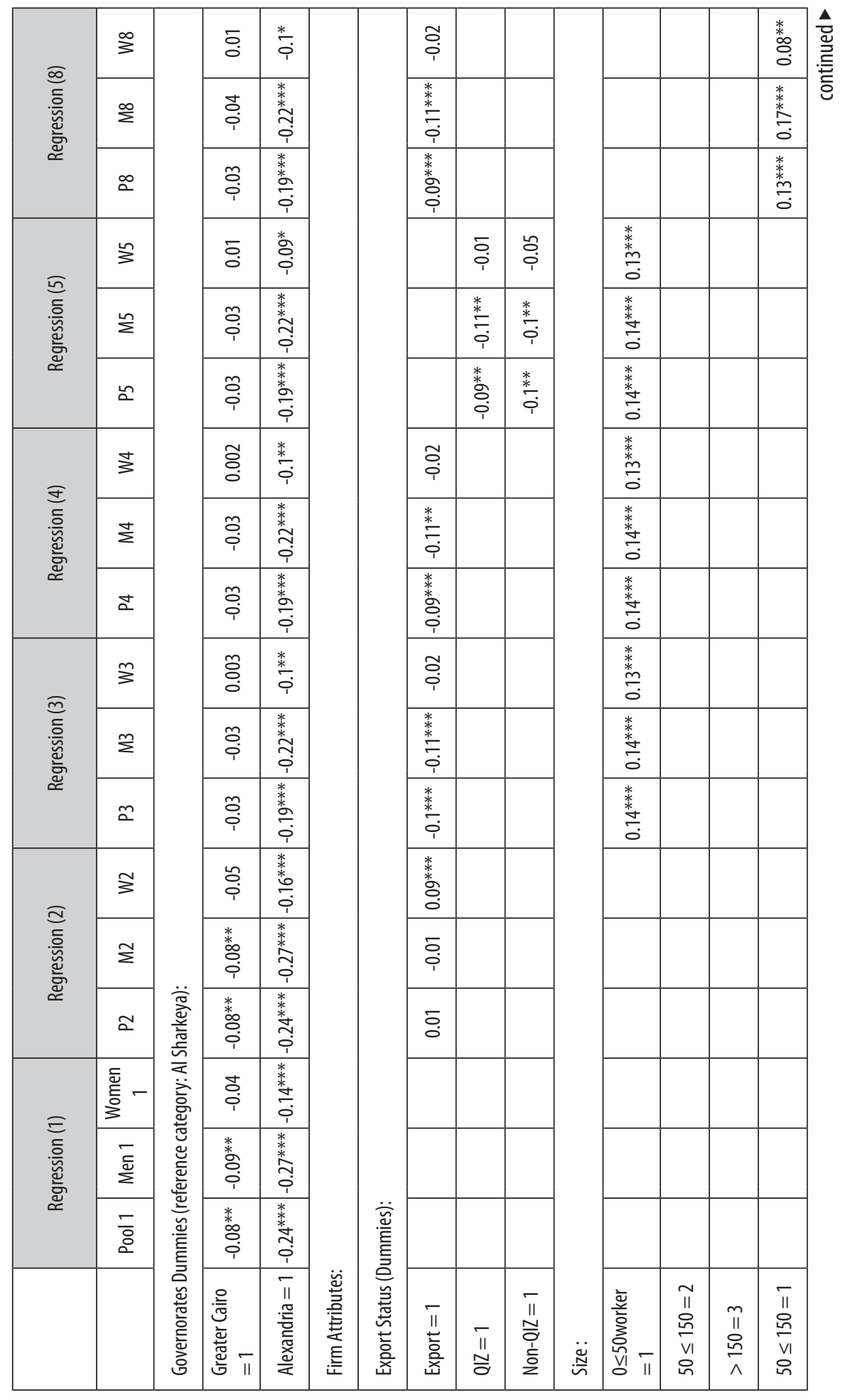




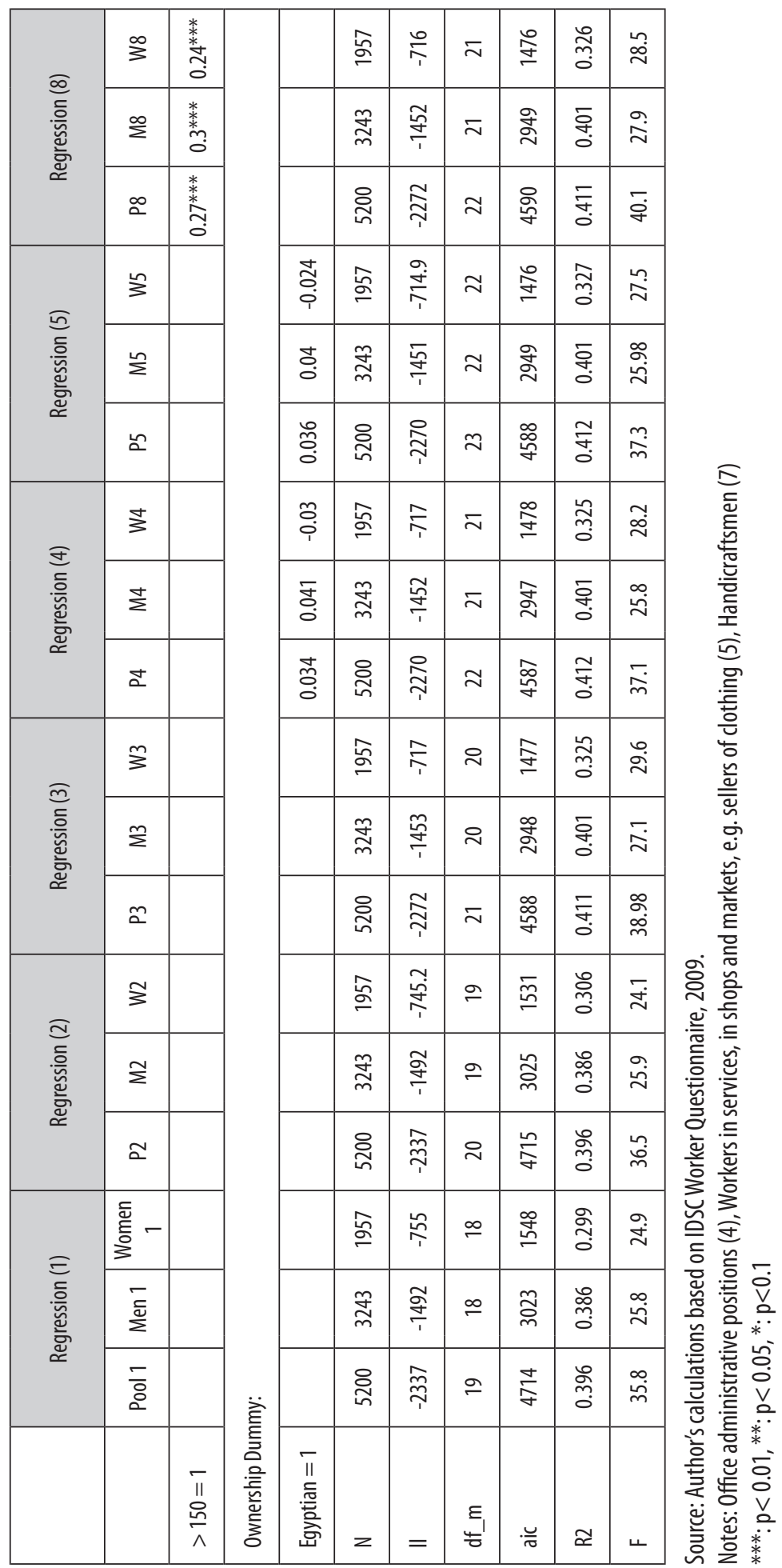




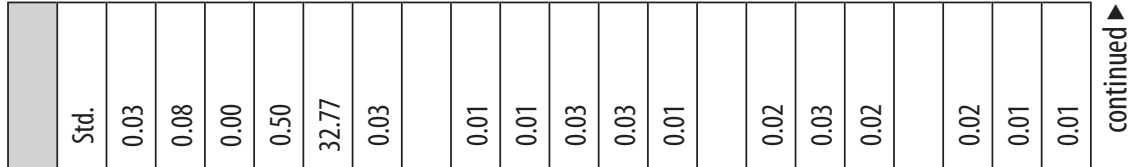

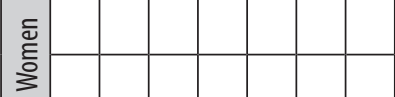

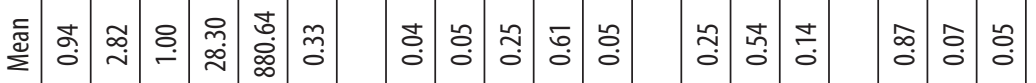

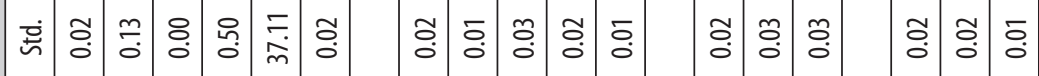

$$
\begin{aligned}
& \frac{\bar{s}}{2}
\end{aligned}
$$

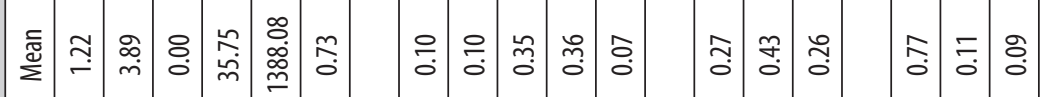

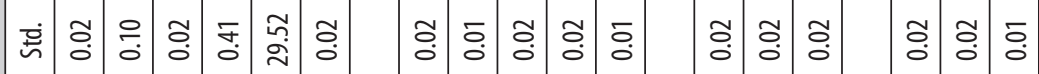

흥

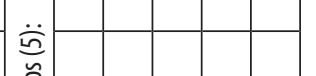

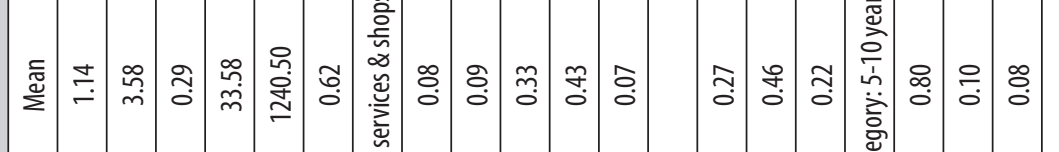

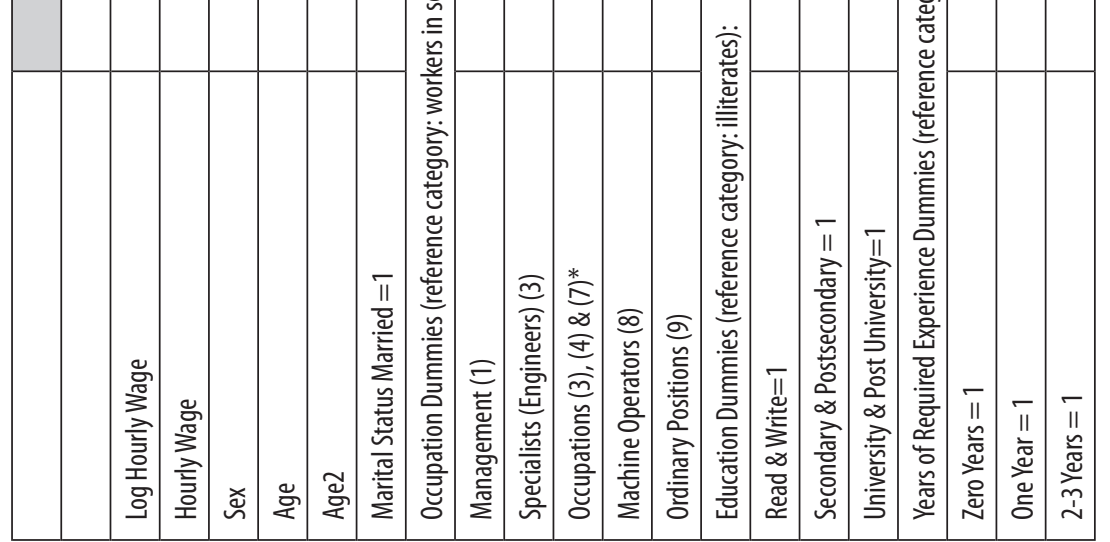




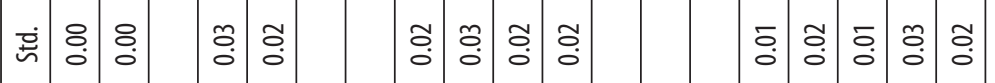
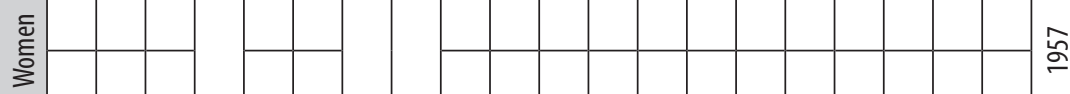

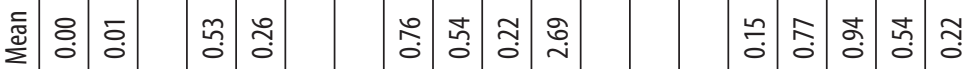

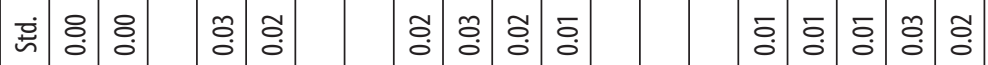

$\stackrel{\bar{\pi}}{2}$

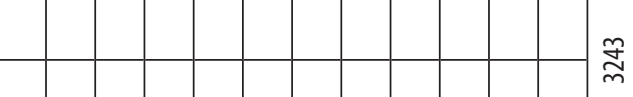

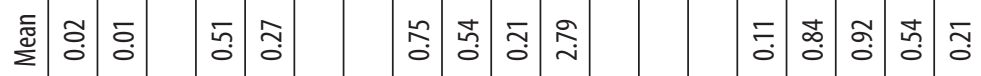

혼

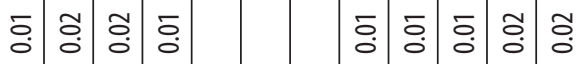
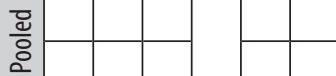

产

范

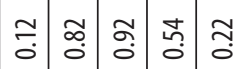

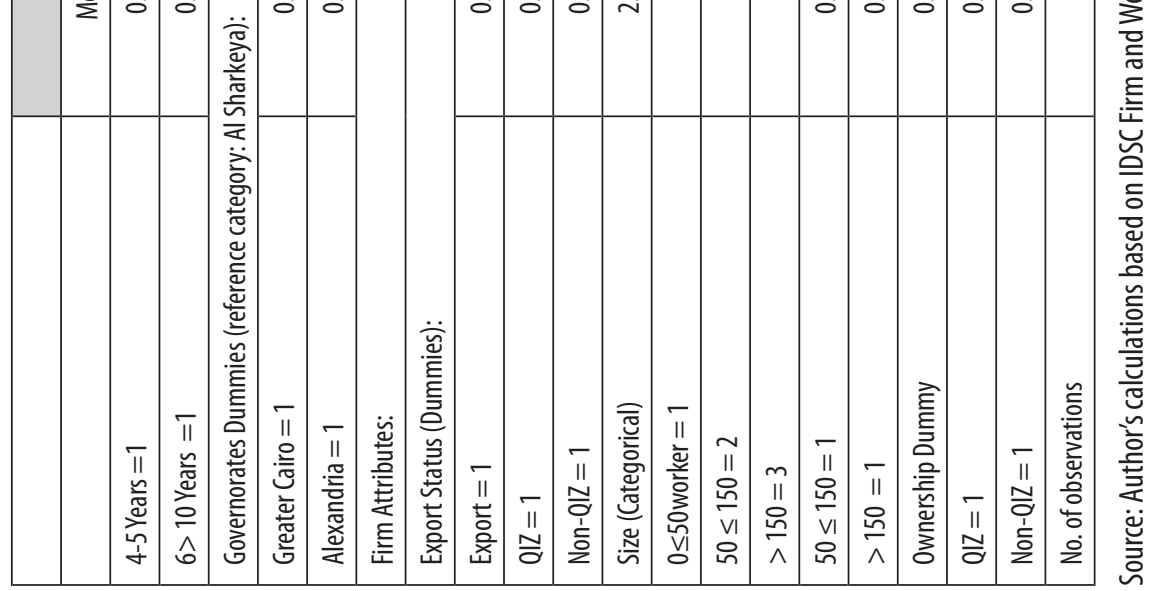



